\title{
The composition and variability of atmospheric aerosol over Southeast Asia during 2008
}

\author{
W. Trivitayanurak ${ }^{1}{ }^{*}$, P. I. Palmer ${ }^{1}$, M. P. Barkley ${ }^{2}$, N. H. Robinson ${ }^{3}$, H. Coe ${ }^{3}$, and D. E. Oram ${ }^{4}$ \\ ${ }^{1}$ School of GeoSciences, University of Edinburgh, Edinburgh, UK \\ ${ }^{2}$ Space Research Centre, University of Leicester, Leicester, UK \\ ${ }^{3}$ Centre for Atmospheric Science, University of Manchester, Manchester, UK \\ ${ }^{4}$ National Centre for Atmospheric Sciences, School of Environmental Sciences, University of East Anglia, Norwich, UK \\ *now at: Department of Highways, Ministry of Transport, Thailand
}

Correspondence to: P. I. Palmer (pip@ed.ac.uk)

Received: 7 July 2011 - Published in Atmos. Chem. Phys. Discuss.: 4 August 2011

Revised: 6 January 2012 - Accepted: 12 January 2012 - Published: 26 January 2012

\begin{abstract}
We use a nested version of the GEOS-Chem global 3-D chemistry transport model to better understand the composition and variation of aerosol over Borneo and the broader Southeast Asian region in conjunction with aircraft and satellite observations. Our focus on Southeast Asia reflects the importance of this region as a source of reactive organic gases and aerosols from natural forests, biomass burning, and food and fuel crops. We particularly focus on July 2008 when the UK BAe-146 research aircraft was deployed over northern Malaysian Borneo as part of the ACES/OP3 measurement campaign. During July 2008 we find using the model that Borneo (defined as Borneo Island and the surrounding Indonesian islands) was a net exporter of primary organic aerosol (42 kT) and black carbon aerosol (11 kT). We find only $13 \%$ of volatile organic compound oxidation products partition to secondary organic aerosol (SOA), with Borneo being a net exporter of SOA $(15 \mathrm{kT})$. SOA represents approximately $19 \%$ of the total organic aerosol over the region. Sulphate is mainly from aqueous-phase oxidation $(68 \%)$, with smaller contributions from gas-phase oxidation $(15 \%)$ and advection into the regions (14\%). We find that there is a large source of sea salt, as expected, but this largely deposits within the region; we find that dust aerosol plays only a relatively small role in the aerosol burden. In contrast to coincident surface measurements over Northern Borneo that find a pristine environment with evidence for substantial biogenic SOA formation we find that the free troposphere is influenced by biomass burning aerosol transported from the northwest of the Island and further afield. We find several transport events during July 2008 over Borneo associated with elevated aerosol concentrations, none of which coincide with
\end{abstract}

the aircraft flights. We use MODIS aerosol optical depths (AOD) data and the model to put the July campaign into a longer temporal perspective. We find that Borneo is where the model has the least skill at reproducing the data, where the model has a negative bias of $76 \%$ and only captures $14 \%$ of the observed variability. This model performance reflects the small-scale island-marine environment and the mix of aerosol species, with the model showing more skill at reproducing observed AOD over larger continental regions such as China where AOD is dominated by one aerosol type. The model shows that AOD over Borneo is approximately evenly split between organic and sulphate aerosol with sea salt representing 10-20\% during May-September; we find a similar breakdown over continental Southeast Asia but with less sea salt aerosol and more dust aerosol. In contrast, East China AOD is determined mainly by sulphate aerosol and a seasonal source of dust aerosol, as expected. Realistic sensitivity runs, designed to test our underlying assumptions about emissions and chemistry over Borneo, show that model AOD is most sensitive to isoprene emissions and organic gas-phase partitioning but all fail to improve significantly upon the control model calculation. This emphasises the multi-faceted dimension of the problem and the need for concurrent and coordinated development of BVOC emissions, and BVOC chemistry and organic aerosol formation mechanisms. 


\section{Introduction}

Tropical forests help influence regional and global climate in a number of ways including physical, chemical and biological processes (Bonan, 2008), but our understanding of these processes is incomplete (e.g. Lewis et al., 2004; Lelieveld et al., 2008; Karl et al., 2010; Martin et al., 2010b). Here, we focus on the Southeast Asian region, where the individual burgeoning economies are progressively dependent on agriculture, manufacturing, and services. Greater pressure on regional agriculture for food and fuel crops, in particular, have led to rapid rates of land use change with implications for the functioning of the forest ecosystems and subsequent impacts on atmospheric composition (Hewitt et al., 2009; Fowler et al., 2011; MacKenzie et al., 2011; Pyle et al., 2011b). Our particular focus is Malaysian Borneo which was the subject of two recent UK-led surface and aircraft measurement campaigns in 2008: (1) OP3 (Oxidant and particle photochemical processes above a South-East Asian tropical rainforest, Hewitt et al., 2010) and (2) ACES (Aerosol Coupling in the Earth System). OP3 had the primary foci of better understanding the production and fate of biogenic volatile organic compounds (BVOCs) emitted by natural forests, and how they impact local to global atmospheric chemistry. ACES had complementary foci associated with the production and fate of SOA from the emitted biogenic VOCs. Here, we use the GEOS-Chem global 3-D model in conjunction with satellite observations of aerosol optical depth to put ACES/OP3 into a wider spatial and temporal perspective and to improve our quantitative understanding of the impact of Malaysian and Indonesian Borneo and its surrounding islands to regional atmospheric composition.

Although Southeast Asia has been studied for wildfires and related chemistry (e.g. Chandra et al., 2002 and Duncan et al., 2003), forest emissions and reactive chemistry over the region has received much less attention than other tropical regions such as South America (e.g. Lelieveld et al., 2008; Martin et al., 2010a), Africa (e.g. Marticorena et al., 2011; Ferreira et al., 2010), and the Indian subcontinent (e.g. Kulshrestha et al., 2001). This might be because Southeast Asia is smaller in geographical area and that interpretation of measurements is more difficult due to the influence of the island-marine biosphere and complex weather systems. For these reasons, integrative efforts have been made through the ACES/OP3 field campaign to improve understandings of organic aerosol through measurements of aerosol composition (Robinson et al., 2011a), aerosol flux (Whitehead et al., 2010) and its precursor VOC fluxes (Langford et al., 2010; Misztal et al., 2010) and the local meteorology and dynamics (Pearson et al., 2010; Whitehead et al., 2010). To better understand formation of BSOA, studies focused on oxidant chemistry (Robinson et al., 2011a; Pike et al., 2010; Pyle et al., 2011a) in conjunction with smog chamber experiments (Hamilton et al., 2011), analysis of air-mass back trajectories (Robinson et al., 2011b), and 0-D chemistry modelling
(Langford et al., 2010; Pike et al., 2010; Pugh et al., 2011), 1D chemistry-transport modelling (Pugh et al., 2010), and 3-D offline chemistry-transport modelling (Pyle et al., 2011b).

In the next section we describe the surface, aircraft, and satellite measurements of trace gases used in this study. Section 3 describes the GEOS-Chem global 3-D chemistry model. Section 4 includes (1) the budget of carbonaceous aerosols and trace gas precursors, sulphur species, sea salt, and dust aerosols during July 2008; (2) an evaluation of the model using aircraft concentration measurements and satellite observations of aerosol optical depth; (3) a study of the seasonal cycle of speciated aerosol extinction over Borneo; (4) a study of the seasonal cycle of aerosol optical depth over Borneo and the larger Southeast Asian region; and (5) sensitivity calculations that explore the robustness of our results to realistic changes in the underlying assumptions. We conclude the paper in Sect. 5 .

\section{Measurements of trace gases and aerosols}

We use aircraft measurements of aerosols and trace gas precursors from the ACES/OP3 campaign over Borneo (Hewitt et al., 2010) during July 2008 to help quantify and understand the aerosol composition of the local and the broader geographical region. First, we use these data to help evaluate the GEOS-Chem global 3-D chemistry transport model. We also use data from the acid deposition monitoring network (EANET) over East Asia to provide additional information about sulphate aerosol over the broader geographical region. Second, we use the GEOS-Chem model and satellite observations of aerosol optical depth to help relate the ACES/OP3 measurements to large spatial and temporal scales.

\subsection{ACES/OP3 aircraft field campaign data}

We focus on the 23 June-23 July (the third and final phase of the OP3 project) because it incorporated aircraft measurements that are generally representative of spatial scales more appropriate for the GEOS-Chem chemistry transport model (Sect. 3). We use measurements from the UK BAe 146 research aircraft, which during the campaign was deployed from Kota Kinabalu airport, less than 30 min flying time from Bukit Atur (BA) Global Atmospheric Watch station $\left(4^{\circ} 58^{\prime} 49.33^{\prime \prime} \mathrm{N}, 117^{\circ} 50^{\prime} 39.05^{\prime \prime} \mathrm{E}, 426 \mathrm{~m}\right.$ a.s.l. $)$ where additional surface measurements were taken. In general, similar flight plans were executed for each flight: one vertical profile, interrupted by straight and level runs at altitudes of 100$250,1500,3000$, and $6000 \mathrm{~m}$ above ground over the rainforest (centred at BA) and over the surrounding landscape including an agro-industrial oil palm plantation. Flights were typically in the morning and afternoon so that some information about diurnal variations of key gases and aerosols could be determined. Table 1 provides a brief overview of the measurements we used for this study. We refer the reader to the 
Table 1. Summary of ACE/OP3 measurements we use from the BAe 146 research aircraft.

\begin{tabular}{|c|c|c|c|c|c|}
\hline Species & Technique & $\begin{array}{l}\text { Temporal } \\
\text { Resolution }\end{array}$ & Limit of Detection & $\begin{array}{l}\text { Measurement } \\
\text { Uncertainty }\end{array}$ & Reference \\
\hline $\begin{array}{l}\text { Speciated aldehydes, ketones } \\
\text { and alcohols, NMHCs, including } \\
\text { isoprene and oxygenates }\end{array}$ & GC/GC detection, PTR-MS & $15 \mathrm{~s}$ & $50-120 \mathrm{pptv}$ & $13-16 \%(1 \sigma)$ & Murphy et al. (2010) \\
\hline $\mathrm{CO}$ & Chemiluminesence & $10 \mathrm{~s}$ & $<2$ ppbv & & Gerbig et al. (1999) \\
\hline $\begin{array}{l}\text { Aerosol size segregated } \\
\text { chemical composition }\end{array}$ & $\begin{array}{l}\text { Aerodyne Aerosol Mass } \\
\text { spectrometer }\left(40 \mathrm{~nm}<D_{\mathrm{vad}}\right. \\
<0.8 \mu \mathrm{m})^{1} \text {, non-refractory }\end{array}$ & $\begin{array}{l}10 \mathrm{~s} \text { (profile) } \\
30 \mathrm{~s}\left(\mathrm{SLR}^{2}\right)\end{array}$ & $\begin{array}{l}\text { 30s average: } \\
\mathrm{SO}_{4}^{2-}: 3 \mathrm{ng} \mathrm{m}^{-3} \\
\text { Organics: } 50 \mathrm{ng} \mathrm{m}^{-3}\end{array}$ & $15 \%$ & Morgan et al. (2010) \\
\hline
\end{tabular}

${ }^{1} D_{\text {vad }}$ is the vacuum aerodynamic diameter.

${ }^{2}$ SLR denotes straight level runs.

OP3 overview paper for a detailed description of the experiment including a comprehensive overview of the measurements (Hewitt et al., 2010).

\subsection{Surface measurements over eastern Asia}

The Acid Deposition Monitoring Network in East Asia (EANET) (http://www.eanet.cc/index.html) reports dry deposition inferred from direct measurements of atmospheric concentration of $\mathrm{SO}_{2}, \mathrm{NO}_{2}, \mathrm{O}_{3}$ and particulate matter, and precipitation measurements of sulphate $\left(\mathrm{SO}_{4}^{2-}\right)$ and nitrate $\left(\mathrm{NO}_{3}^{-}\right)$. The network includes 51 sites over East and Southeast Asian countries that are classified as remote (20), rural (12), and urban (19). We use the rural sites, defined as being between 20 and $50 \mathrm{~km}$ away from large pollution sources and $500 \mathrm{~m}$ away from heavy traffic roads, to evaluate model longrange transport of sulphur-containing compounds. We chose to report the total sulphur (ppbv) rather than to test the model skill at partitioning between $\mathrm{SO}_{2}$ and $\mathrm{SO}_{4}^{2-}$, which would be more appropriate for a separate study.

\subsection{Satellite observations of aerosol optical depth}

We use aerosol optical depth (AOD) observations from the NASA Moderate Resolution Imaging Spectroradiometer (MODIS) aboard the Aqua EOS satellite, which was launched in 2002 into a sun-synchronous orbit with an equatorial local overpass time of 13:30 p.m. local. MODIS provides near-global daily retrievals of AOD in cloud-free and glint-free conditions using independent algorithms over land (Levy et al., 2007a,b) and ocean (Levy et al., 2003; Remer et al., 2005; Tanre et al., 1997) Over ocean, MODIS aerosol retrievals use a look-up table approach in which a combination of one fine and one coarse lognormal aerosol mode is chosen based on the best least-square fit of the computed spectral reflectance to the MODIS-observed spectral reflectance. Over land, the retrieval uses a combination of multi-modal models, one dominated by fine mode (but containing both fine and coarse modes) and one dominated by coarse mode (but containing two modes). Over ocean, AOD products are provided at seven channels $(470,550,660,870$, 1240,1630 , and $2130 \mathrm{~nm}$ ), and over land AOD products are provided at four channels $(470,550,660$, and $2130 \mathrm{~nm})$.

We have chosen to use the standard MODIS AOD products. Innovative, new products that, for example, improve the aerosol properties that help determine the AOD retrieval prior (e.g. Drury et al., 2010) could lead to better agreement with our model but a comprehensive analysis of this effect over Southeast Asia is outside the scope of this study.

To examine AOD over Borneo, we use the MODIS L2 AOD by joining ocean AOD $\left(\tau_{\text {ocean }}\right)$ and land AOD $\left(\tau_{\text {land }}\right)$, selecting values of $\tau_{\text {ocean }}$ with Quality Assurance Confidence (QAC) no less than 1 and values of $\tau_{\text {land }}$ with QAC of 3. To examine AOD over the broader Southeast Asian region, we use the MODIS L3 daily gridded joint land and ocean AOD product at $550 \mathrm{~nm}$ from the Collection 5 MODIS algorithm products, which has an estimated uncertainty of $\pm 0.05 \pm 0.15 \tau$ over land (Levy et al., 2010) and $\pm 0.03 \pm 0.05 \tau$ over ocean (Remer et al., 2005). The L3 product includes the number of pixels used to calculate the daily mean $1^{\circ} \times 1^{\circ}$ AOD product, which we use to screen out scenes where less than six measurements are used. We also use the fine-mode scaling factor provided as standard by the MODIS team that yields the fine-mode AOD, $\tau_{\mathrm{f}}$, from the total AOD. MODIS AOD tends to be biased high in cloudy regions such as Borneo; thin cirrus clouds can artifically increase AOD by $\simeq 0.02$ (L. Remer, personal communication, NASA, 2011) and the AOD over Southeast Asia islands remains unvalidated against the Aerosol Robotic Network (AERONET) (Levy et al., 2010).

\section{Description of the nested GEOS-Chem chemistry transport model}

We use the GEOS-Chem chemistry transport model (v802-01, http://www.geos-chem.org), driven by analyzed meteorological fields from the NASA Global Modeling and 
Table 2. Global monthly emissions of aerosols and gaseous precursors from GEOS-Chem simulation of 2008.

\begin{tabular}{|c|c|c|c|c|c|c|c|c|c|c|c|c|c|c|c|c|}
\hline \multirow[t]{2}{*}{ Month } & \multicolumn{3}{|c|}{$\begin{array}{c}\mathrm{SO}_{2} \\
\mathrm{Tg} \mathrm{S} \text { month }^{-1}\end{array}$} & \multirow{2}{*}{$\begin{array}{c}\mathrm{SO}_{4}^{2-} \\
\mathrm{Tg} \mathrm{S}^{-1}{ }^{-1}{ }^{-1} \\
\mathrm{FF}+\mathrm{BF}\end{array}$} & \multirow[t]{2}{*}{ 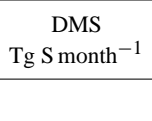 } & \multicolumn{3}{|c|}{$\begin{array}{c}\mathrm{BC}^{1} \\
\operatorname{Tg~month}^{-1}\end{array}$} & \multicolumn{3}{|c|}{ 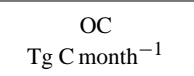 } & \multicolumn{3}{|c|}{$\begin{array}{c}\text { BVOCs } \\
\text { Tg C month }\end{array}$} & \multirow[t]{2}{*}{$\begin{array}{c}\text { Dust } \\
\text { Tg month }^{-1}\end{array}$} & \multirow[t]{2}{*}{$\begin{array}{c}\text { Sea salt } \\
\text { Tg month }^{-1}\end{array}$} \\
\hline & $\mathrm{FF}^{2}$ & $\mathrm{BB}$ & $\mathrm{BF}$ & & & $\mathrm{FF}$ & BB & $\mathrm{BF}$ & $\mathrm{FF}$ & $\mathrm{BB}$ & $\mathrm{BF}$ & Isoprene & Monoterpene & MBO & & \\
\hline 1 & 5.4 & 0.15 & 0.01 & 0.10 & 2.1 & 0.28 & 0.38 & 0.13 & 0.28 & 2.9 & 0.60 & 31 & 6 & 0.02 & 187 & 567 \\
\hline 2 & 5.1 & 0.07 & 0.01 & 0.10 & 2.2 & 0.29 & 0.18 & 0.14 & 0.29 & 1.4 & 0.61 & 29 & 6 & 0.03 & 216 & 567 \\
\hline 3 & 5.1 & 0.13 & 0.01 & 0.10 & 1.9 & 0.28 & 0.30 & 0.13 & 0.28 & 2.3 & 0.59 & 33 & 6 & 0.04 & 178 & 565 \\
\hline 4 & 5.4 & 0.07 & 0.01 & 0.10 & 1.5 & 0.28 & 0.15 & 0.13 & 0.27 & 1.4 & 0.59 & 30 & 7 & 0.05 & 280 & 534 \\
\hline 5 & 5.2 & 0.05 & 0.01 & 0.10 & 1.3 & 0.27 & 0.10 & 0.13 & 0.26 & 0.9 & 0.58 & 30 & 8 & 0.10 & 231 & 528 \\
\hline 6 & 5.4 & 0.05 & 0.01 & 0.10 & 1.4 & 0.27 & 0.12 & 0.13 & 0.26 & 1.0 & 0.58 & 33 & 9 & 0.18 & 232 & 583 \\
\hline 7 & 5.4 & 0.09 & 0.01 & 0.10 & 1.3 & 0.27 & 0.21 & 0.13 & 0.25 & 1.7 & 0.57 & 38 & 10 & 0.26 & 227 & 577 \\
\hline 8 & 5.4 & 0.17 & 0.01 & 0.10 & 1.4 & 0.27 & 0.39 & 0.13 & 0.25 & 3.1 & 0.57 & 39 & 10 & 0.25 & 161 & 570 \\
\hline 9 & 5.2 & 0.23 & 0.01 & 0.10 & 1.1 & 0.27 & 0.54 & 0.13 & 0.26 & 4.2 & 0.58 & 39 & 8 & 0.11 & 114 & 574 \\
\hline 10 & 5.4 & 0.07 & 0.01 & 0.10 & 1.2 & 0.27 & 0.16 & 0.13 & 0.27 & 1.3 & 0.58 & 37 & 7 & 0.05 & 152 & 601 \\
\hline 11 & 5.2 & 0.05 & 0.01 & 0.10 & 1.9 & 0.28 & 0.12 & 0.13 & 0.27 & 0.9 & 0.59 & 32 & 6 & 0.03 & 95 & 526 \\
\hline 12 & 5.4 & 0.07 & 0.01 & 0.10 & 2.2 & 0.28 & 0.20 & 0.13 & 0.28 & 1.4 & 0.59 & 31 & 6 & 0.02 & 143 & 529 \\
\hline
\end{tabular}

${ }^{1} \mathrm{DMS}, \mathrm{BC}, \mathrm{OC}$, and BVOCs refer to dimethylsulphide, black carbon, organic carbon, and biogenic volatile organic compounds, respectively.

2 FF, BB, BF, and MBO refer to fossil fuel, biomass burning, biofuel, and methylbutenol, respectively.

Assimilation Office (GMAO) Global Earth Observing System (GEOS) model, to interpret ground-based, aircraft, and satellite observations of trace gases and aerosols during 2008. With reference to Southeast and mainland Asia, GEOSChem has been evaluated using a wide range of in situ (e.g. Kiley et al., 2003; Palmer et al., 2003; Park et al., 2005; Palmer et al., 2006), and satellite data (e.g. Heald et al., 2004; Shim et al., 2005; Fu et al., 2007). Here we use GEOS-5 meteorological fields with 47 vertical layers and a temporal resolution of $6 \mathrm{~h}$ for meteorology and $3 \mathrm{~h}$ for surface quantities including mixing depths. The simulation includes a description of $\mathrm{NO}_{\mathrm{x}}-\mathrm{O}_{\mathrm{x}}$-hydrocarbon-aerosol chemistry (Bey et al., 2001a,b). The model is initialized with an 11-month global full-chemistry simulation at a horizontal resolution of $4^{\circ}$ latitude by $5^{\circ}$ longitude. For subsequent global model calculations over the period 1 December 2007 to 1 January 2009 we use a horizontal resolution of $2^{\circ}$ latitude by $2.5^{\circ}$ longitude. For our regional one-way nested, model calculations during June-July 2008 we use the native GEOS-5 horizontal resolution $0.5^{\circ}$ latitude by $0.67^{\circ}$ longitude over a China-Southeast Asia domain described by $70-150^{\circ} \mathrm{E}$ and $10^{\circ} \mathrm{S}-55^{\circ} \mathrm{N}$. Boundary conditions for this calculations are taken from the $4^{\circ}$ latitude by $5^{\circ}$ longitude calculation, with a temporal resolution of $3 \mathrm{~h}$, consistent with GEOS-5 surface fields. Details of the nested-grid formulation can be found in Wang et al. (2004) and Chen et al. (2009). Figure 1 describes the source regions over which we track individual contributions to AOD. We found that our results for Borneo were similar to that of the closest neighbouring regions. Consequently, we decided to lump them together for the model calculations so that from hereinafter Borneo is defined as Borneo Island plus the closest neighbouring Indonesian islands Sumatra, Java, Sulawesi, and the Lesser Sunda Islands.

Table 2 shows our estimated emissions of sulphate, organic carbon (OC), black carbon (BC), sea salt, dust, and biogenic precursors to SOA (Alexander et al., 2005; Fair-

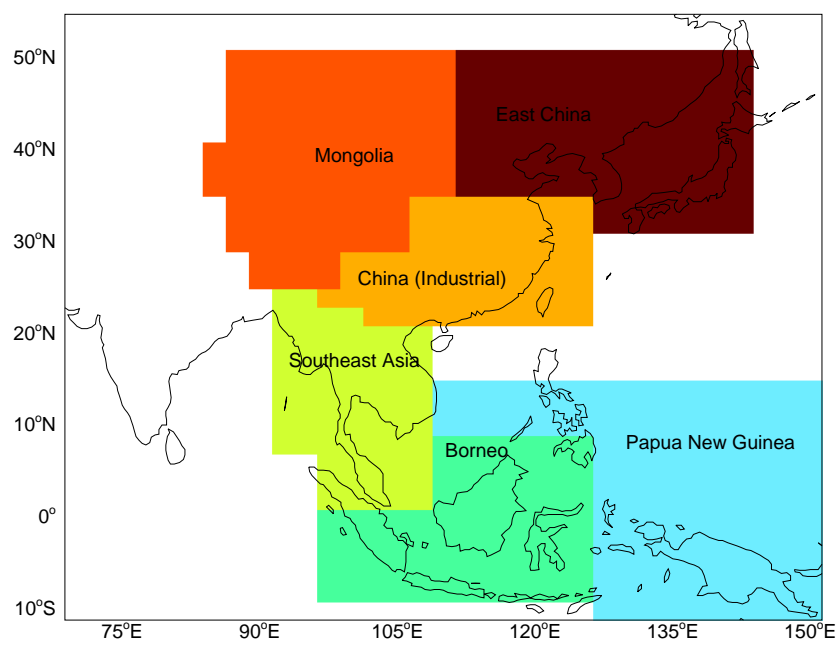

Fig. 1. Geographical source regions used throughout this study to interpret results from the GEOS-Chem global 3-D chemistry transport model with a nested region described by $70-150^{\circ} \mathrm{E}$ and $-11-$ $55^{\circ} \mathrm{N}$ that uses a horizontal resolution of $0.5^{\circ}$ latitude by $0.67^{\circ}$ longitude.

lie et al., 2010; Henze and Seinfeld, 2006; Park et al., 2003, 2004). For sea salt, we distinguish between an accumulation mode (dry radius $0.1-0.5$ microns) and a coarse mode (dry radius 0.5-4 microns) (Jaeglé et al., 2011). Similarly, we describe dust using four size ranges with effective radii of 0.7 , 1.5, 2.5, and 4 microns, respectively. For radiative transfer calculations, dust is segregated into 7 size bins, but for atmospheric transport and deposition calculations dust in the first four size bins, covering $0.01-1 \mu \mathrm{m}$, are lumped together. The remaining aerosol types are treated as bulk mass.

We use sulphur emissions based on the Global Emissions Inventory Activity (GEIA) for 1985 with updated national emission inventories and fuel use data (Bey et al., 
2001b; Park et al., 2004). We use more recent inventories for Asia (Streets et al., 2003, 2006), Europe (http://www. emep.int), the United States (http://www.epa.gov/ttn/chief/ net/1999inventory.html), Mexico (Kuhns et al., 2005), and Canada (http://www.ec.gc.ca/pdb/cac/). We assume that anthropogenic sulphur is emitted primarily as $\mathrm{SO}_{2}$, with only a small fraction as sulphate (5\% in Europe, $1.4 \%$ North America, and $3 \%$ elsewhere, Chin et al., 2000).

We include carbonaceous emissions from fossil fuel and biofuel combustion (Bond et al., 2004), biomass burning (van der Werf. et al. , 2006), and SOA precursors from biogenic VOCs. We use the Model of Emissions of Gases and Aerosols from Nature (MEGAN, version 2.1) (Guenther et al., 2006) to describe biogenic VOC emissions from terrestrial vegetation. MEGAN is used to calculate emission rates for isoprene, methylbutenol (MBO), and several monoterpene compounds ( $\alpha$-pinene, $\beta$-pinene, limonene, myrcene, sabinene, 3 -carene and ocimene), using the parameterized canopy environment emission activity (PCEEA) algorithm (Sakulyanontvittya et al., 2008). The emissions, E, of these compounds are parameterized by:

$E=E_{0} \times \gamma_{\mathrm{CE}} \times \gamma_{\mathrm{Age}} \times \gamma_{\mathrm{SM}} \times \rho_{\mathrm{env}}$,

where $E_{0}$ are the basal emissions ( $\mu$ g of compound $\mathrm{m}^{-2} \mathrm{~h}^{-1}$ ) normalized to standard conditions, which are multiplied by emission activity factors that simulate changes in the emission rate owing to the changes in the canopy environment $\left(\gamma_{\mathrm{CE}}\right)$, leaf age $\left(\gamma_{\mathrm{Age}}\right)$, and soil moisture $\left(\gamma_{\mathrm{SM}}\right)$. In this study we neglect the effect of soil moisture $\left(\gamma_{\mathrm{SM}}=1\right)$. We assume standard conditions for production and loss of the BVOC within the canopy, represented by the normalized ratio $\rho_{\text {env }}$, by setting $\rho_{\text {env }}=1$.

The basal MEGAN emission factors are regridded from a default $0.5^{\circ} \times 0.5^{\circ}$ grid to the GEOS-Chem horizontal resolutions and driven by 3-hourly surface air temperatures (at $2 \mathrm{~m}$ height), and by diffuse and direct photosynthetic active radiation from the GEOS-5 analyses. We use a version of MEGAN that incorporates elevated isoprene emissions from natural vegetation but does include emissions from oil palm plantations. Our nested model grid resolution of $0.5^{\circ} \times 0.67^{\circ}$ will not be sufficient to describe the sharp spatial variations in land-use between natural and oil palm vegetation observed during ACES/OP3. To simulate changes in vegetation we use monthly mean MODIS observations of leaf-area index (LAI, vC5) gridded at $0.25^{\circ} \times 0.25^{\circ}$ (Myneni et al, 2007). The average LAI for vegetated areas within each grid cell, $\mathrm{LAI}_{\mathrm{v}}$, is estimated by dividing the LAI by the fraction of the cell covered by vegetation following the approach of Guenther et al. (2006) and Müller et al. (2008). These monthly LAI $\mathrm{L}_{\mathrm{v}}$ fields are then re-mapped to the GEOS-Chem grid (Barkley et al., 2011). Simulation years outside 2000-2008 use a climatology based on the available MODIS observations. SOA chemistry is calculated using experimental aerosol yield parameters fitted to the two-product model (Chung and Seinfeld,
2002) and partitioned onto the existing organic aerosol, following the SOA implementation in the GISS GCM (Chung and Seinfeld, 2002 and references therein; Henze and Seinfeld, 2006). Table 2 summarizes the monthly mean emissions of each aerosol and aerosol precursor for 2008.

We calculate optical depths that directly feed into the photolysis rate calculation used by the $\mathrm{NO}_{\mathrm{x}}-\mathrm{O}_{\mathrm{x}}$-hydrocarbon chemistry. We use the updated aerosol physical and optical properties consistent with that in a later release of GEOSChem model (v8-02-05, http://www.geos-chem.org). The update incorporates improvement in the size distribution of sulphate, OC, BC (Drury et al., 2010) and sea salt Jaeglé et al. (2011). We calculate AOD $\tau$ using the following relation (Tegen and Lacis, 1996):

$$
\tau=\frac{3}{4} \frac{Q_{\mathrm{ext}} M}{r_{\mathrm{eff}} \rho}=\alpha M,
$$

where $Q_{\text {ext }}$ is Mie scattering extinction efficiency factor, $M$ is the column mass loading $\left(\mathrm{g} \mathrm{m}^{-2}\right), \rho$ is the aerosol density $\left(\mathrm{g} \mathrm{m}^{-3}\right), r_{\text {eff }}$ is the effective radius (m), and $\alpha$ is the aerosol mass extinction $\left(\mathrm{m}^{2} \mathrm{~g}^{-1}\right)$. BC has the strongest extinction at low $\mathrm{RH}$, with the more hygroscopic species having more influence at RH values larger than $50 \%$ (not shown). Coarse dust, despite its lower $\alpha$ values than other accumulationmode aerosols, has a stronger extinction per particle because it has a mass-per-particle that is three orders of magnitude bigger than other accumulation-mode aerosols. For our analysis of AOD we account for contributions from individual sources (BC, OC, dust, and sea salt) and from geographical regions shown by Fig. 1.

\section{GEOS-Chem model budget and model comparison against measurements}

In this section we present a budget and an evaluation of the control model configuration; we also discuss how sensitive our results are to realistic changes in our underlying assumptions.

\subsection{Model aerosol budget over Borneo}

Tables 3, 4, 5, and 6 summarize the budget of carbonaceous aerosols and trace gas precursors, sulphur species, sea salt and dust, respectively, over Borneo (Fig. 1) during the ACES/OP3 measurement period 25 June-25 July 2008. The average total column aerosol burden over this region is $28 \times 10^{9} \mathrm{~g}$, comprising sulphate $(10 \%)$, primary OA $(22 \%), \mathrm{SOA}(5 \%), \mathrm{BC}(4 \%)$, sea salt $(50 \%)$, and dust $(9 \%)$. The total column burden for accumulation-mode aerosol is $14 \times 10^{9} \mathrm{~g}$ comprising sulphate $(23 \%)$, primary organic aerosol $(43 \%)$, SOA $(10 \%)$, BC $(7 \%)$, sea salt $(6 \%)$, and dust $(11 \%)$. We use a "tagged" CO simulation (not shown), for which the $\mathrm{OH}$ is fixed and taken from a full-chemistry simulation, to provide the origin and age of airmasses sampled over Borneo. A description of the tagged $\mathrm{CO}$ simulation 
Table 3. GEOS-Chem model budget of primary organic aerosol and black carbon over Borneo, 25 June-25 July, 2008.

\begin{tabular}{|c|c|c|}
\hline & $\begin{array}{c}\text { Primary } \\
\text { Organic Aerosol }\end{array}$ & $\begin{array}{l}\text { Black } \\
\text { Carbon }\end{array}$ \\
\hline \multicolumn{3}{|l|}{ Emissions $\left(\mathrm{kT} \mathrm{month}^{-1}\right)$ : } \\
\hline Anthropogenic & 62 & 22 \\
\hline Biomass burning & 110 & 7 \\
\hline Biofuel & 124 & 16 \\
\hline Transport into region $\left(\mathrm{kT}\right.$ month $\left.{ }^{-1}\right)$ & 36 & 4 \\
\hline Total source & 332 & 49 \\
\hline Dry deposition (kT month $\left.{ }^{-1}\right)$ & 1 & 0.1 \\
\hline Wet deposition (kT month $\left.{ }^{-1}\right)$ & 229 & 30 \\
\hline Transport out of region $\left(\mathrm{kT}\right.$ month $\left.{ }^{-1}\right)$ & 78 & 15 \\
\hline Total sink & 308 & 45 \\
\hline Burden $(\mathrm{kT})$ & 6 & 1 \\
\hline Lifetime (days) & 0.6 & 0.7 \\
\hline
\end{tabular}

can be found in Bey et al. (2001a) and Gonzi and Palmer (2010). Here, we use CO as a proxy for OA from fossil fuel and biomass combustion, acknowledging this approach will generally overestimate the influence of long-range transport on the regional budget. We find that fossil fuel emissions from Borneo represent $26 \%$ of the local budget, with $19 \%$ originating from Java and Sulawesi islands, $13 \%$ from East Asia, $8 \%$ from South Asia, $7 \%$ from continental Southeast Asia and Sumatra, with the remainder from long-range transport. For biomass burning, local emissions contribute $41 \%$, while long-range transport from Africa, Australia, and South America contribute $19 \%, 18 \%$, and 6\%, respectively.

We find that Borneo for the June/July period is a net exporter of carbonaceous aerosol (Tables 3,4), with only approximately $10 \%$ of this aerosol and trace gas precursors from incoming air masses. The predominant winds for this period originate largely from the tropical Pacific so that downwind regions include continental Southeast Asian countries and the southeastern coast of China. We find that only $13 \%$ of secondary organic gas, produced via volatile organic compound oxidation, is able to partition and remain in the aerosol phase to form SOA (Table 4). Over the study region, our calculations show that SOA contributes approximately $23.5 \%$ to total OA. Our model SOA contribution is significantly lower than those reported for other remote locations (Jimenez et al., 2009) and this model issues will be explored in sensitivity calculations. There is an approximate balance between sources and sinks of BC and of OA.

Table 5 shows that sulphate over Borneo is mainly from aqueous-phase oxidation (68\%), with smaller contributions from gas-phase oxidation $(15 \%)$ and advection into the region $(14 \%)$. Regional $\mathrm{SO}_{4}^{2-}$ is almost entirely deposited within the region (76\%); this agrees with the OP3 aircraft observations during June/July 2008 (Robinson et al., 2012), which observe depleted sulphate aerosol loading as the air- mass travels across the region. The resulting atmospheric lifetime, determined mainly by loss due to wet deposition, is 0.5 days. The contribution from dimethysulfide (DMS) is small despite the proximity of potential ocean sources, in agreement with measurements (J. Hopkins, personal communication, University of York, UK, 2010).

Table 6 shows that sea salt aerosol over Borneo originates in equal measure from local emissions within the study region and from airmasses advected into the regions. The budget also indicates that sea salt mostly wet deposits within the local region. The model atmospheric lifetime for sea salt in accumulation and coarse modes is approximately 0.6 days. With no local dust emission sources, long-range transport is the only source of dust that represents a few percent to the AOD (not shown).

\subsection{Comparison of model and aircraft and satellite observations}

\subsubsection{Concentration profiles}

We use aircraft measurements of key trace gases and aerosols from the ACES/OP3 experiment (Sect. 2) to test model vertical gradients of key trace gases and aerosols. We sample the model along the flight tracks and average the model and measurements in a consistent manner. We anticipate that these data are representative of regional emissions that can be captured by the global 3-D model.

Figure 2 shows that the model vertical distributions of organics, $\mathrm{SO}_{4}^{2-}$, isoprene, and the sum of methyl vinyl ketone (MVK) and methacrolein (MACR) reproduce the observed sharp vertical gradient around $900 \mathrm{hPa}$. We generally find that model concentrations above the boundary layer reduce with altitude faster than the observations, suggesting a lack of efficient vertical transport from the boundary layer, as observed from aircraft (Robinson et al., 2012), and/or reflect the comparison between point measurements and an average over the $0.5^{\circ} \times 0.67^{\circ}$ model grid cell.

Model CO concentrations agree with observations with a positive bias of typically $20-30 \%$ in the boundary layer and of $5-10 \%$ in the free troposphere; the model also captures the maxima between 700 and $800 \mathrm{hPa}$, which represents regional and long-range transport of biomass burning pollution. We find that $\mathrm{CO}$ in the boundary layer and free troposphere are largely from local biomass burning and longrange transport, respectively. Good agreement in the free troposphere provides some confidence in the GEOS-5 meteorological analyses. The large positive model bias of $\mathrm{CO}$ in the boundary layer suggest a gross overestimation of local combustion sources; this bias is also shown in the model organics.

Modelling the rapid variation in $\mathrm{SO}_{4}^{2-}$ is particularly challenging, reflected in large biases and negative correlations in Table 7. The median statistics shows that the model misses the observed peak between $700-800 \mathrm{hPa}$ which may be due 
Table 4. GEOS-Chem model budget of secondary organic gas and secondary organic aerosol over Borneo, 25 June-25 July 2008.

\begin{tabular}{|c|c|c|}
\hline & $\begin{array}{c}\text { Secondary organic gas } \\
\text { (Aerosol conversion) }\end{array}$ & $\begin{array}{c}\text { Secondary organic } \\
\text { aerosol }\end{array}$ \\
\hline \multicolumn{3}{|l|}{ In situ chemical production $\left(\mathrm{kT}\right.$ month $\left.{ }^{-1}\right)$ : } \\
\hline$\alpha$-pinenes + limonene + other terpenes & $190(24)$ & 24 \\
\hline Alcohols & $40(8)$ & 8 \\
\hline Sequiterpenes & $75(15)$ & 15 \\
\hline Isoprene & $400(43)$ & 43 \\
\hline Transport into region $\left(\mathrm{kT} \mathrm{month}^{-1}\right)$ & 84 & 12 \\
\hline Total source & 790 & 102 \\
\hline Dry deposition (kT month ${ }^{-1}$ ) & 7 & 0.2 \\
\hline Wet deposition $\left(\mathrm{kT}\right.$ month $\left.{ }^{-1}\right)$ & 380 & 71 \\
\hline Transport out of region $\left(\mathrm{kT}\right.$ month $\left.{ }^{-1}\right)$ & 134 & 27 \\
\hline Total sink & 611 & 98 \\
\hline Burden (kTon) & 10 & 1 \\
\hline Lifetime (days) & 0.5 & 0.4 \\
\hline
\end{tabular}

to pollutant transport from upwind anthropogenic and/or marine sources; previous studies have highlighted the highsulphur content of biomass burning fuel over the study region (Duncan et al. (2003) and references therein). We find a negative model bias $(-35 \%)$ in reproducing surface measurements of total sulphur from the EANET surface network (not shown) but find that the model reproduces more than $50 \%$ of the observed variability (Pearson correlation $r=0.74, n=152$ ). There is evidence for the $\mathrm{SO}_{4}^{2-}$ peak between $700-800 \mathrm{hPa}$, during flights over East Sabah, originating from the marine boundary layer (Robinson et al., 2012); we examine the importance of DMS in the sensitivity calculations below.

Model isoprene and its oxidation products MVK + MACR show a positive bias below $900 \mathrm{hPa}(\simeq 2 \mathrm{ppbv})$ and a fasterthan-observed fall-off with altitude, which may suggest model error in boundary layer mixing or radical chemistry. Overprediction of near-surface isoprene concentrations agrees with previous work (Langford et al., 2010) that showed the MEGAN model overpredicted isoprene emission rates at the OP3 surface sites by a factor of 4 . The model vertical profile of organics, the sum of POA and SOA, reflects the model performance of gas-phase tracers of combustion and biogenic activity. The measurements show most variation in the free troposphere peaking at $700-800 \mathrm{hPa}$; Robinson et al. (2012) describes this air layer during flights over East Sabah to be composed of lofted marine-origin air with organic aerosol that gradually takes up BSOA en route across the Northern tip of Borneo. Tracers of biomass burning were not significantly elevated during the ACES/OP3 flights, however the $700-800 \mathrm{hPa}$ free tropospheric layer was influenced by long-range transport of combustion pollution at other times. Below in the sensitivity calculations, we investigate further the role of regional and long-range transport of biomass burning emissions over Borneo.

\subsubsection{Aerosol optical depth and aerosol extinction profiles}

Space-borne observations of aerosol optical properties provide an opportunity to relate the aircraft campaign to broader temporal and spatial scales. We focus our analysis on NASA MODIS data (Sect. 2); other analyses using data from the Cloud-Aerosol Lidar and Infrared Pathfinder Satellite Observation (CALIPSO), not shown, showed similar results but the observed aerosol extinction coefficient has not been validated at the time of writing.

Figure 3 compares MODIS and model AOD at $550 \mathrm{~nm}$ over Southeast Asia for July 2008. We sample the model at the location of each Level 2 mean scene and regrid the data onto the $0.5^{\circ} \times 0.67^{\circ}$ nested grid. The model generally has a negative bias of $51 \%$ over ocean, reflecting the percentage difference of smaller values in the model. The model has a negative bias of $56 \%$ over Borneo. The model and data are therefore consistent between model-satellite and model-aircraft comparisons. Figure 3 also shows the percentage contributions of the AOD from $\mathrm{SO}_{4}^{2-}, \mathrm{BC}, \mathrm{OC}$, salt (accumulation and coarse modes), and dust. Over Borneo the largest contribution is from $\mathrm{OC}$ originating from biomass burning on the Northwest of the Island. These emissions are determined in part by active firecount measurements from the MODIS instrument (Fig. 4) which show extensive burning over Borneo including over the northern tip close to the measurement campaign, and on the upwind islands of Sumatra and Java. As we show below these emissions influence the free troposphere above the Danum Valley measurement site. The second largest contribution to AOD over Borneo is from $\mathrm{SO}_{4}^{2-}$ mainly from oxidation of local anthropogenic $\mathrm{SO}_{2}$ emissions and to a smaller extent from upwind sulphurrich Guinea emissions. Our model only shows a few percent of the AOD is from sea salt and BC. 
Table 5. GEOS-Chem model sulphur budget over Borneo, 25 June-25 July 2008.

\begin{tabular}{|c|c|c|c|}
\hline $\mathbf{S O}_{2}$ & & $\mathbf{S O}_{4}^{2-}$ & \\
\hline Sources (kT S month ${ }^{-1}$ ) & & Sources (kT S month ${ }^{-1}$ ) & \\
\hline Emissions: & & Gas phase & 8.4 \\
\hline Anthropogenic & 100 & Aqueous oxidation & 38 \\
\hline Biomass burning & 2.9 & Oxidation on seasalt & 0.04 \\
\hline Biofuel & 0.8 & Transport into region & 8.0 \\
\hline DMS oxidation: & & Total source & 56 \\
\hline $\mathrm{DMS}+\mathrm{OH}$ & 1.4 & & \\
\hline $\mathrm{DMS}+\mathrm{NO}_{3}$ & 1.4 & Sinks (kT S month $\left.{ }^{-1}\right)$ & \\
\hline Transport into region & 3.0 & Dry deposition & 0.1 \\
\hline \multirow[t]{2}{*}{ Total source } & 110 & Wet deposition & 41 \\
\hline & & Transport out of region & 13 \\
\hline Sinks (kT S month ${ }^{-1}$ ) & & Total sink & 54 \\
\hline \multicolumn{4}{|l|}{ Chemical Loss: } \\
\hline $\mathrm{SO}_{2}+\mathrm{OH}$ & 8.4 & Burden (kT S) & 0.9 \\
\hline $\mathrm{SO}_{2}+\mathrm{H}_{2} \mathrm{O}_{2}$ & 38 & Lifetime (days) & 0.5 \\
\hline $\mathrm{SO}_{2}+\mathrm{O}_{3}$ & 0.2 & & \\
\hline $\mathrm{SO}_{2}+\mathrm{O}_{3}$ (on salt) & 0.0 & & \\
\hline Dry deposition & 1.2 & & \\
\hline Wet deposition & 32 & & \\
\hline Transport out of region & 5.2 & & \\
\hline Total sink & 85 & & \\
\hline Burden (kT S) & 0.7 & & \\
\hline Lifetime (days) & 0.2 & & \\
\hline DMS & & MSA & \\
\hline Emissions (kT S month ${ }^{-1}$ ): & 2.5 & Sources (kT S month ${ }^{-1}$ ) & \\
\hline Transport into region $\left(\mathrm{kT} \mathrm{S} \mathrm{month}{ }^{-1}\right.$ ) & 1.0 & DMS oxidation & 0.2 \\
\hline \multirow[t]{2}{*}{ Total source } & 3.5 & Transport into region & 0.8 \\
\hline & & Total source & 0.9 \\
\hline Chemical Loss: & & Sinks (kT S month ${ }^{-1}$ ) & \\
\hline $\mathrm{DMS}+\mathrm{OH}$ & 1.6 & Dry deposition & 0.0 \\
\hline $\mathrm{DMS}+\mathrm{NO}_{3}$ & 1.4 & Wet deposition & 0.3 \\
\hline Transport out of region $\left(\mathrm{kT} \mathrm{S} \mathrm{month}{ }^{-1}\right.$ ) & 0.5 & Transport out of region & 0.6 \\
\hline Total sink & 3.6 & Total sink & 0.9 \\
\hline Burden (kT S) & 0.02 & Burden (kT S) & 0.02 \\
\hline Lifetime (days) & 0.1 & Lifetime (days) & 0.6 \\
\hline
\end{tabular}

To investigate the transport pathways of the aerosols that contribute to observed AOD variations, we report the aerosol extinction profiles over the Danum Valley study site. Figure 5 shows the total model vertical aerosol extinction associated with the total column optical depth and its contributions from $\mathrm{SO}_{4}^{2-}, \mathrm{BC}, \mathrm{OC}$, sea salt (accumulation and coarse modes), and dust. The largest values of aerosol extinction are in the boundary layer close to their sources emissions, as expected. We find that boundary layer values are determined largely by OC from primary and secondary sources. Perhaps, more interesting is the large percentage contributions of $\mathrm{OC}$ in the free troposphere which we have related to long-range trans- port of incomplete combustion supported by coincident elevated $\mathrm{CO}$ concentrations. These long-range transport events occur with a frequency on the order of two weeks. Unfortunately, the aircraft flights, denoted by black squares on the top of Fig. 5, did not coincide with these transport events. There is also a percentage contribution from $\mathrm{SO}_{4}^{2-}$ in the free troposphere but generally only on days when AOD is relatively low. Sea salt is a small, diffuse source of aerosol extinction, while dust contributes only small absolute values. As described in Sect. 3 aerosol mass extinction is a function of relative humidity and aerosol optical properties. As such it is difficult to reliably attribute the model bias in AOD to any 
Table 6. GEOS-Chem model sea salt budget over Borneo, 25 June25 July, 2008.

\begin{tabular}{lrrr}
\hline Size Range & $0.1-0.5 \mu \mathrm{m}$ & $0.5-4.0 \mu \mathrm{m}$ & Total: $0.1-4.0 \mu \mathrm{m}$ \\
\hline Sources (kT month & -1 \\
Emissions & & & \\
Transport into region & 15 & 419 & 434 \\
Total source & 16 & 371 & 387 \\
& $\mathbf{3 1}$ & $\mathbf{7 9 0}$ & $\mathbf{8 2 1}$ \\
Sinks (kT month & \\
Dry deposition & & & \\
Wet deposition & 0.01 & 2.3 & 2.3 \\
Transport out of region & 22 & 496 & 518 \\
Total sink & 7.2 & 172 & 179 \\
& $\mathbf{2 9}$ & $\mathbf{6 7 1}$ & $\mathbf{7 0 0}$ \\
Burden (kT) & & & \\
Lifetime (days) & 0.6 & 13 & 14 \\
& 0.6 & 0.6 & 0.6 \\
\hline
\end{tabular}

one or more aerosol types beyond the, admittedly ad hoc, methods employed here.

Figure 6 shows timeseries of MODIS and model AOD for different geographical regions during 2008. We also show the speciated contributions to each timeseries. First, we regrid the daily mean $1^{\circ} \times 1^{\circ}$ Level 3 MODIS data onto the model horizontal resolution of $2^{\circ} \times 2.5^{\circ}$ for comparison, accounting for the number of observations included in each daily average, as described above, and average the comparison over 10-day periods over the region. MODIS AOD over Borneo is typically $<0.4$, peaking at 0.4 during February due to a transport pattern from the China region that affects the Southeast Asian region. Model AOD has a $76 \%$ negative bias over the year and reproduces only $14 \%$ of the AOD variability observed by MODIS $(r=0.38)$. The model attributes most of the AOD to sulphur, OC, and sea salt. There is also a small source from BC, and during July-September we see a small source from dust aerosol. Although MODIS AOD is expected to be biased high for cloudy scenes and the retrieval is challenging for low AOD values $(\tau<0.15)$ due to surface reflectance issues (Levy et al., 2010), these uncertainties do not explain all the model bias. Agreement between the model and MODIS AOD over larger continental regions with Southeast Asia vary from large discrepancies for continental Southeast Asia $(r=0.45$, bias $=-53 \%)$, to small percentage bias but low correlations for China Industrial $(r=0.32$, bias $=12 \%$ ), to East China where the bias is low and the correlation is high $(r=0.82$, bias $=15 \%)$. Agreement between model and observed AOD over the remote oceans (e.g. temperate Southern Ocean, $-180-180^{\circ} \mathrm{E}, 20-50^{\circ} \mathrm{S}$, is very good $(r=0.75$, bias $=0.63 \%)$ where AOD is determined mainly by changes in sea salt aerosol, but over oceans that include considerable continental outflow, e.g. the tropical Indian ocean where during some time of the year continental outflow can represent more than $50 \%$ of the AOD, the bias is high but the model describes the larger scale seasonal cycle $(r=0.76$, bias $=-49 \%)$.
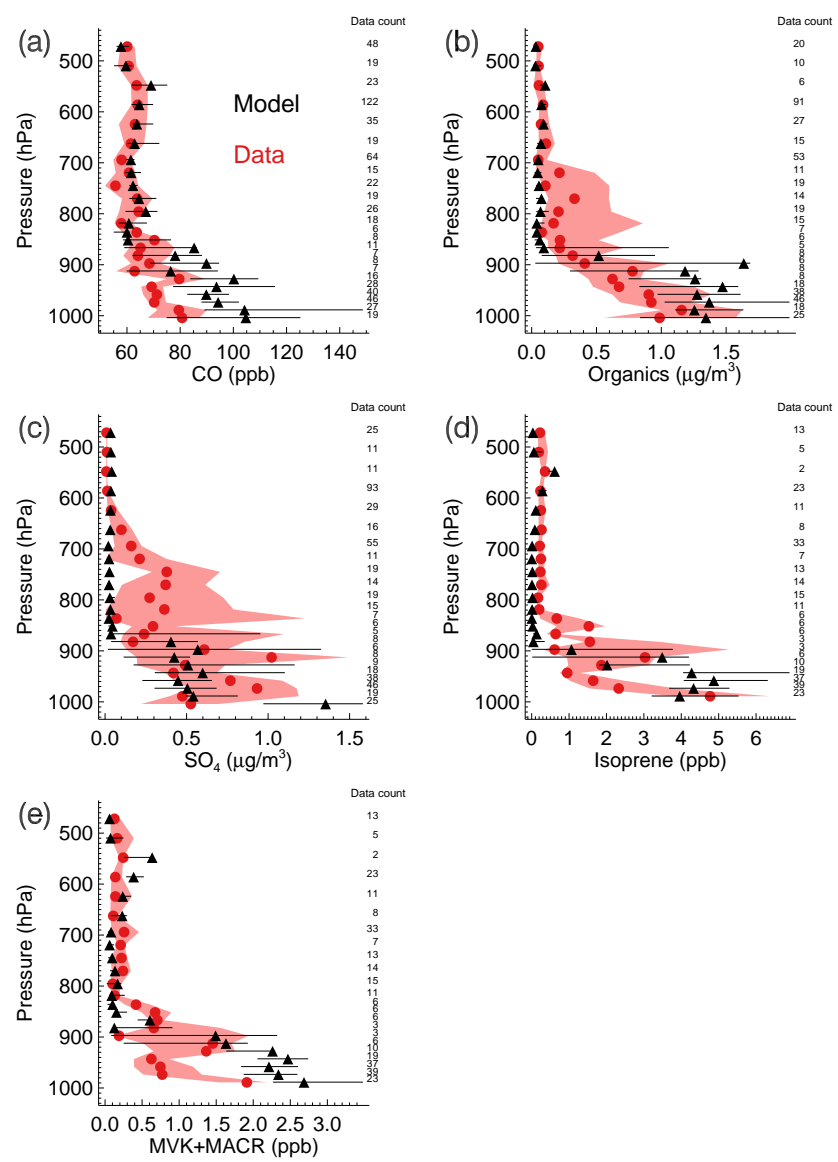

Fig. 2. Median statistics for BAe $146 \mathrm{UK}$ research aircraft (red circle) and GEOS-Chem model (black triangle) concentration profiles for (a) $\mathrm{CO}[\mathrm{ppb}]$, (b) organic aerosol $\left[\mu \mathrm{g} \mathrm{m}^{-3}\right]$, (c) $\mathrm{SO}_{4}^{2-}$ $\left[\mu \mathrm{g} \mathrm{m}^{-3}\right]$, (d) Isoprene [ppb], and (e) the sum of methyl vinyl ketone (MVK) and methacrolein (MACR) during July 2008 as part of the ACES/OP3 measurement campaign. The nested grid model is sampled at the same time and location of each aircraft measurement along the flight track. The black horizontal lines and the pink shaded envelope denote the 25 th and 75 th percentiles, respectively. The number of data points used at each altitude is shown in the R.H.S. axis of each panel.

\subsection{Sensitivity calculations}

It is clear from our model comparison with aircraft and satellite measurements that the model suffers from errors in surface emissions, and/or atmospheric chemistry and transport. We explore the robustness of our results to realistic changes in the underlying assumptions we make in our control calculation. Tables 7 and 8 report the results from six sensitivity calculations. 
Table 7. Mean percentage bias, model minus data, and Pearson correlation coefficient (in brackets) between the ACES/OP3 aircraft data and the GEOS-Chem global 3-D chemistry transport model that has been sampled at the time and location of the data for the BASE run. The sensitivity runs PAR, BB, SULF, DMS, and SEA (described in Sect. 4) are expressed as the percentage change relative to BASE, with the correlation coefficient change relative to the BASE case (in bracket). PBL, MIX, and LFT are defined as pressure $P>915$ hPa, $915 \mathrm{hPa}>P>740 \mathrm{hPa}$, and $\mathrm{P}<740 \mathrm{hPa}$, respectively, following Robinson et al. (2012).

\begin{tabular}{llrrrrrr}
\hline Species/Altitude & & BASE & PAR & BB & SULF & DMS & SEA \\
\hline $\mathrm{CO}$ & LFT & $6(0.27)$ & $0(0.00)$ & $11(-0.01)$ & $0(0.00)$ & $2(-0.01)$ & $1(0.00)$ \\
& MIX & $9(0.58)$ & $0(0.00)$ & $12(0.01)$ & $0(0.00)$ & $2(-0.02)$ & $2(0.01)$ \\
& PBL & $30(0.31)$ & $0(-0.01)$ & $17(0.00)$ & $0(0.00)$ & $2(-0.01)$ & $2(0.00)$ \\
\hline Organic aerosol & LFT & $85(0.01)$ & $231(-0.13)$ & $27(0.00)$ & $0(0.00)$ & $0(0.00)$ & $2(-0.01)$ \\
& MIX & $-12(0.28)$ & $75(-0.01)$ & $8(0.00)$ & $0(0.00)$ & $0(0.00)$ & $0(0.00)$ \\
& PBL & $72(0.05)$ & $289(-0.05)$ & $39(0.01)$ & $0(0.00)$ & $0(0.00)$ & $1(0.01)$ \\
\hline $\mathrm{SO}_{4}^{2-}$ & LFT & $139(-0.14)$ & $1(0.00)$ & $1(-0.01)$ & $25(-0.05)$ & $1(0.00)$ & $0(0.00)$ \\
& MIX & $80(-0.09)$ & $1(0.00)$ & $1(0.00)$ & $8(-0.02)$ & $1(0.00)$ & $0(0.01)$ \\
& PBL & $39(-0.31)$ & $0(0.00)$ & $2(0.00)$ & $7(0.00)$ & $0(0.00)$ & $0(-0.01)$ \\
\hline Isoprene & LFT & $-45(0.11)$ & $0(0.00)$ & $-1(0.00)$ & $0(0.00)$ & $0(0.00)$ & $17(-0.02)$ \\
& MIX & $-68(0.57)$ & $0(0.01)$ & $0(0.01)$ & $0(0.00)$ & $0(0.00)$ & $5(0.00)$ \\
& PBL & $189(-0.13)$ & $0(0.00)$ & $-10(0.00)$ & $0(0.00)$ & $0(-0.01)$ & $86(0.01)$ \\
\hline \multirow{2}{*}{ MVK+MACR } & LFT & $52(-0.14)$ & $0(-0.01)$ & $-2(0.00)$ & $1(-0.01)$ & $1(0.00)$ & $40(-0.01)$ \\
& MIX & $21(0.41)$ & $0(0.00)$ & $-3(0.01)$ & $0(0.00)$ & $0(0.00)$ & $24(-0.02)$ \\
& PBL & $240(0.28)$ & $0(0.00)$ & $0(-0.01)$ & $1(0.00)$ & $0(0.00)$ & $53(0.04)$ \\
\hline
\end{tabular}

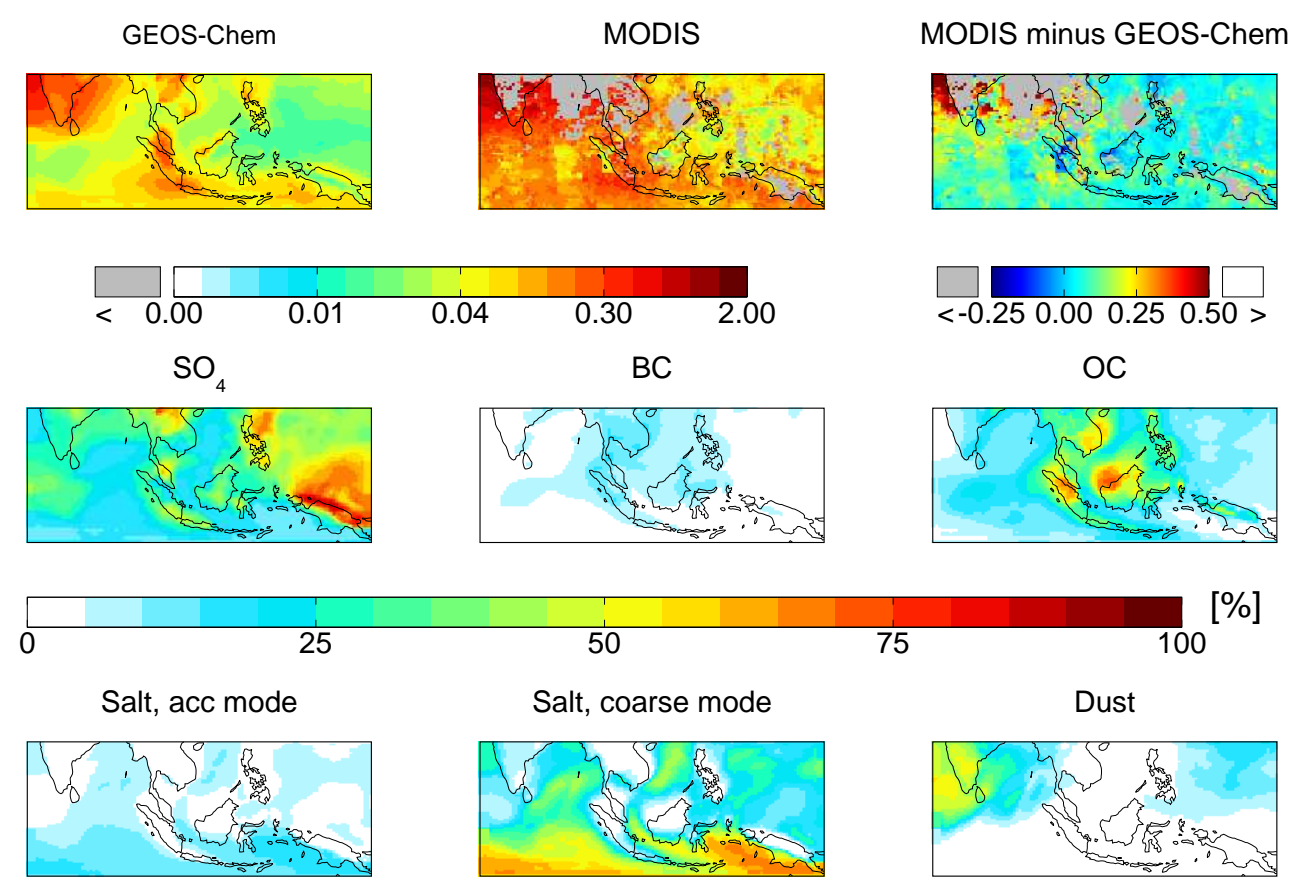

Fig. 3. MODIS and GEOS-Chem model aerosol optical depths [unitless] and their differences for July 2008. The model has been sampled at the same time and location as the observations. Contributions to the model AOD from $\mathrm{SO}_{4}^{2-}$, black carbon (BC), organic aerosol (OC), sea salt (accumulation and coarse modes), and desert dust. 
Table 8. Mean model percentage error (correlation $r$ ) compared to MODIS AOD measurements.

\begin{tabular}{lrrrrrr}
\hline Domain & BASE $^{1}$ & PAR $^{2}$ & BB $^{3}$ & SULF $^{4}$ & DMS $^{5}$ & SEA $^{6}$ \\
\hline Borneo & $-76(0.38)$ & $-54(0.41)$ & $-72(0.40)$ & $-75(0.40)$ & $-71(0.44)$ & $-76(0.38)$ \\
Continental SE Asia & $-54(0.45)$ & $-37(0.48)$ & $-46(0.55)$ & $-48(0.43)$ & $-53(0.45)$ & $-54(0.46)$ \\
China Industrial & $12(0.32)$ & $18(0.37)$ & $15(0.37)$ & $19(0.35)$ & $12(0.32)$ & $12(0.32)$ \\
East China & $15(0.82)$ & $19(0.83)$ & $19(0.84)$ & $21(0.82)$ & $15(0.82)$ & $-15(0.82)$ \\
\hline
\end{tabular}

${ }^{1}$ Control run as described in the main text. ${ }^{2}$ Control run $\times 100$ global increase in gas-aerosol partitioning coefficient. ${ }^{3}$ Control run $+100 \%$ increase in global biomass burning emissions. ${ }^{4}$ Control run $+40 \%$ global increase in anthropogenic $\mathrm{SO}_{2}$ and $\mathrm{SO}_{4}^{2-}$ emissions. ${ }^{5}$ Control run increase of southern oceanic DMS emissions by monthly scaling factors (see main text). ${ }^{6}$ Control run $20 \%$ increase in Southeast Asian isoprene emissions.

\subsubsection{Sensitivity to emissions}

We showed above that the model underestimates the source of $\mathrm{OC}$ and $\mathrm{BC}$ for which the main common source would be biomass burning. The uncertainty associated with biomass burning is large enough to permit a factor of two increase (e.g. Kopacz et al., 2010), which we use to test this source of error. Here we apply their upper limit in the BB calculation. Table 7 shows that this leads to an increase in concentrations that consequently improves the model organic aerosol concentration bias in the MIX by $8 \%$ but increases model positive bias in the PBL and LFT; slight increases in the model positive bias of $\mathrm{SO}_{4}^{2-}$; and an increased positive model bias in CO. Table 8 shows these changes translate to only very small reductions in the model AOD bias.

To investigate an error in sulphate aerosol, we independently adjust emissions from anthropogenic and natural sources. First we increased global anthropogenic emissions of $\mathrm{SO}_{2}$ and $\mathrm{SO}_{4}^{2-}$ by $40 \%$ in the SULF calculation. The magnitude of this increase is based on (a) the $36 \%$ negative model bias we found against the EANET surface observations, and (b) failure of GEOS-Chem to reproduce increased AOD over major cities over Southeast Asia, such as Bangkok, for which fossil fuel combustion is the dominant sulphur source. Table 7 shows that increased sulphate emissions increases the model positive bias throughout the vertical profile. The bias increases the most in the LFT (by $25 \%$ ) suggesting long-range transport influence over the OP3 aircraft experiment domain. Table 8 shows the $40 \%$ increase in sulphur emissions results in small AOD changes that typically decrease the bias against MODIS.

To test the natural source of sulphate in the model, we looked at AOD over the remote Southern Ocean where aerosols are dominated by sea salt and marine-origin sulphate. MODIS AOD has a strong seasonal cycle over the remote Southern Ocean $\left(40^{\circ} \mathrm{S}-60^{\circ} \mathrm{S}\right)$, peaking in Austral Summer (December to February), reflecting changes in phytoplankton photosynthetic activity and resulting emissions of DMS, which the model does not reproduce (not shown). Model AOD is generally aseasonal throughout the year with a value similar to the observed Austral Winter AOD, while
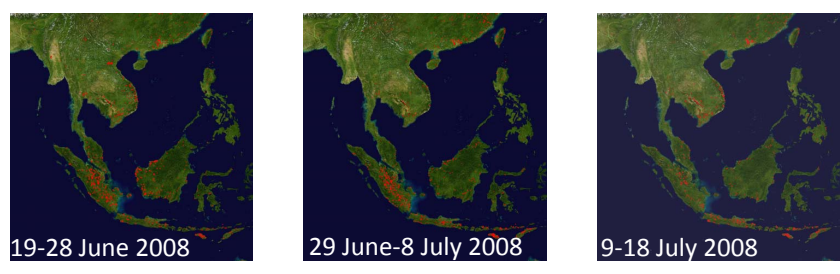

Fig. 4. NASA MODIS fire count distributions from 19 June-18 July 2008 in 10-day intervals (http://rapidfire.sci.gsfc.nasa.gov/).

the $\mathrm{SO}_{4}^{2-}$ contribution does not capture the observed strong seasonal, suggesting an error in the DMS emission and/or the sea salt emission parameterization which is known to be poor at high winds. We scale the model DMS emissions by using the monthly ratio between MODIS fine-mode AOD and model AOD contribution from sulphur over the Southern ocean remote from other aerosol sources. By increasing DMS concentration in the Southern Hemisphere at the cost of over predicting AOD over the Southern Ocean, we find improvement in AOD over the tropical ocean regions more significantly than the improvement in other scenarios for the same regions. We find that the increase in DMS worsens the AOD bias between MODIS and GEOS-Chem over the Southern Ocean ( $46 \%$ to $83 \%$ ) but improves the description of the seasonal cycle. The increased DMS results in slight bias improvement in AOD over Borneo ( $-76 \%$ to $-71 \%$ ); for in situ aircraft comparison, the results are $1 \%$ increases in the model positive biases in the MIX and LFT, which can partially contribute to the missing peak between $700-800 \mathrm{hPa}$. This result emphasizes the importance of including the seasonal cycle of DMS and improving the air-sea exchange parameterization.

\subsubsection{Sensitivity to gas-phase partitioning to secondary organic aerosol}

The SOA model we use is based on calculations of the firstgeneration reactions in smog chamber experiments (Griffin et al., 1999), and therefore will underpredict the ultimate SOA production from the VOC precursors. By increasing the gas-particle partitioning coefficients of all SOA by a factor 

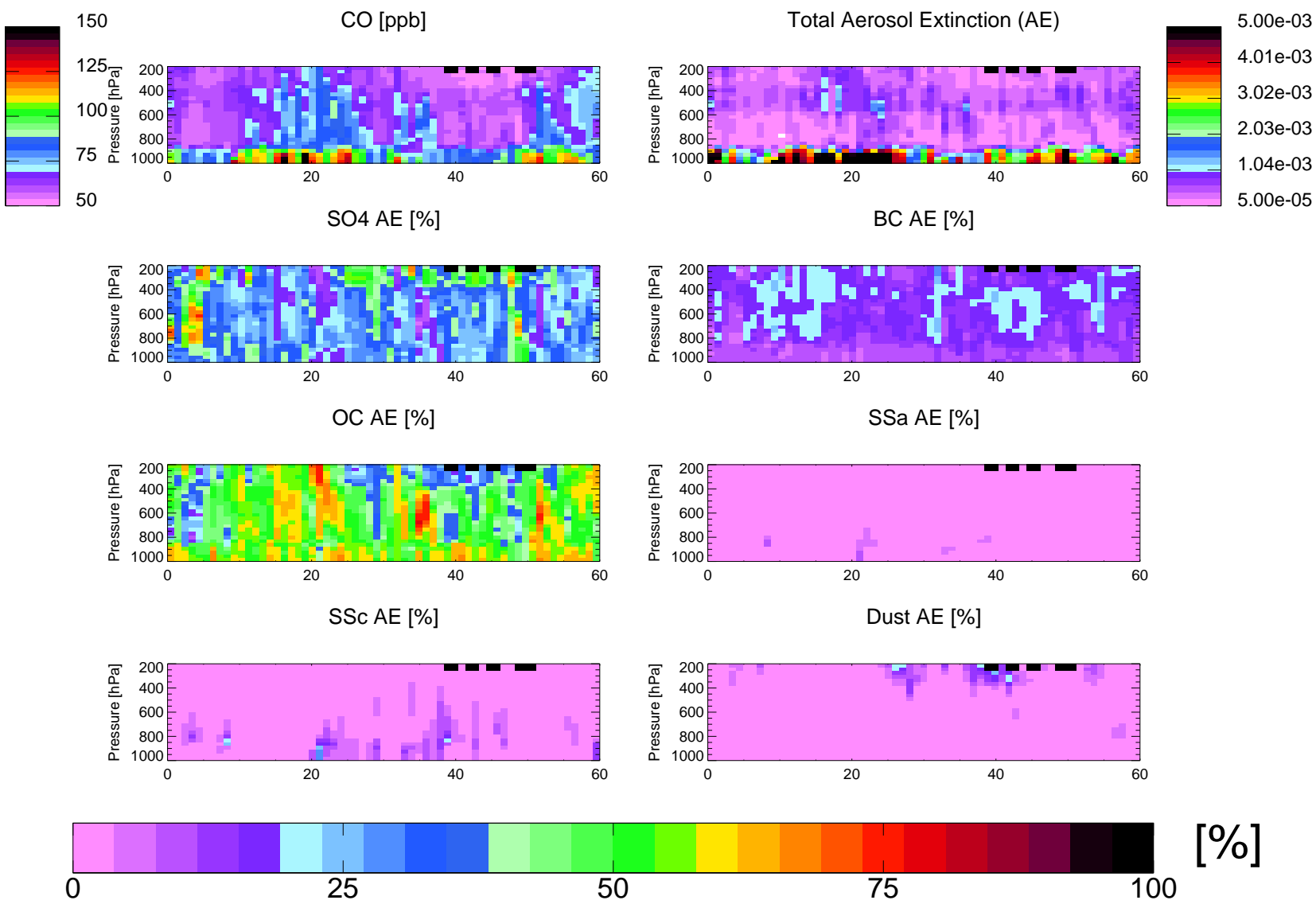

Fig. 5. Model vertical profiles of $\mathrm{CO}$ [ppb], aerosol extinction and its percentage source contributions from sulphate, black carbon (BC), organic carbon (OC), sea salt in accumulation (SSa) and coarse (SSc) modes, and desert dust for June-July 2008 (described as the days from 1 June 2008). The black squares at the top of each panel denote the days on which there were ACES/OP3 aircraft flights.

of 100, we account for subsequent generations of oxidations that further lower their volatility. A similar factor was necessary to match model and observed organic aerosol over the Amazon basin (Hodzic et al., 2009).

Table 8 shows that for this calculation we see the largest increases over tropical ecosystems, as expected, where the emissions of BVOCs and resulting production of SOA is largest. Increasing the partitioning uniformly increases the SOA formation and so does improve the model temporal variations. Model AOD over tropical South America (not shown) increased by $151 \%$ resulting in reduced bias against MODIS from $-64 \%$ to $-9 \%$, and model AOD over Borneo increase by $91 \%$ resulting in a reduction in bias from $-76 \%$ to $-54 \%$. Putting the in situ comparison into context, Table 7 shows that the improvement in AOD is associated with a large increase in model bias in organic aerosol concentration. The larger change over the Amazon due to the enhanced partitioning reflects the larger contributions to AOD from BVOCs. The improvement over the tropical continents also results in better agreement in downwind regions such as the tropical Pacific Ocean. For some regions, the comparison against MODIS AOD gets worse, highlighting that a single change in partitioning is not ideal for all environments.

\subsubsection{Global impact of Southeast Asian BVOC emissions}

To quantify the effect of BVOCs from Southeast Asia to the rest of the world, we increase the isoprene emission from Southeast Asia region $\left(90-130^{\circ} \mathrm{E},-10-20^{\circ} \mathrm{N}\right)$ by $20 \%$ in the SEA simulation. Table 7 shows large increases of isoprene concentrations ( $5 \%$ to $86 \%$ ) and isoprene products ( $24 \%$ to $53 \%$ ) associated with this perturbation to emissions; but only a few percent bias increases in organic aerosol. The global effect of this regional increase in isoprene is very small overall. The largest reduction of AOD bias occurs over Borneo from $-77 \%$ to $-76 \%$ while for other regions bias reduction is insignificant. Comparing predicted AOD in the SEA simulation to the BASE simulation, Borneo increases by $0.9 \%$ while immediate neighboring regions increase by typically $0.3 \%$. The changes extend 

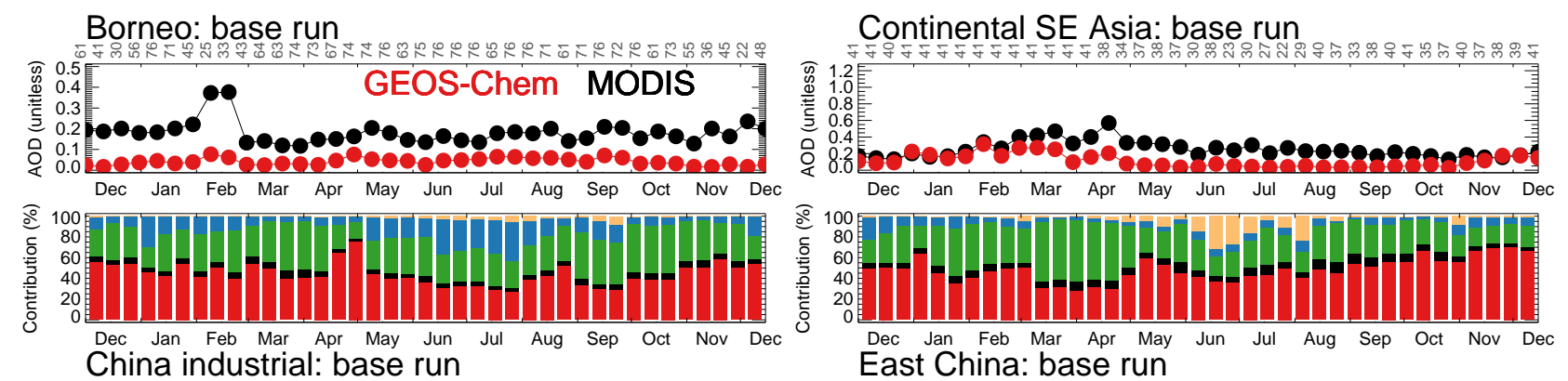

China industrial: base run

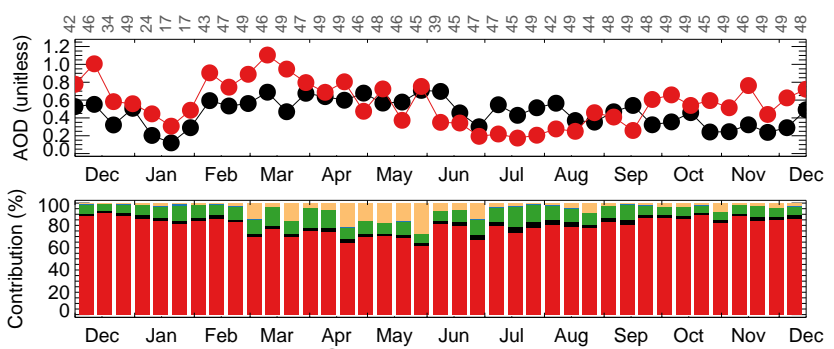

Dec Jan Feb Mar Apr May Jun Jul Aug
Tropical Indian Ocean: base run
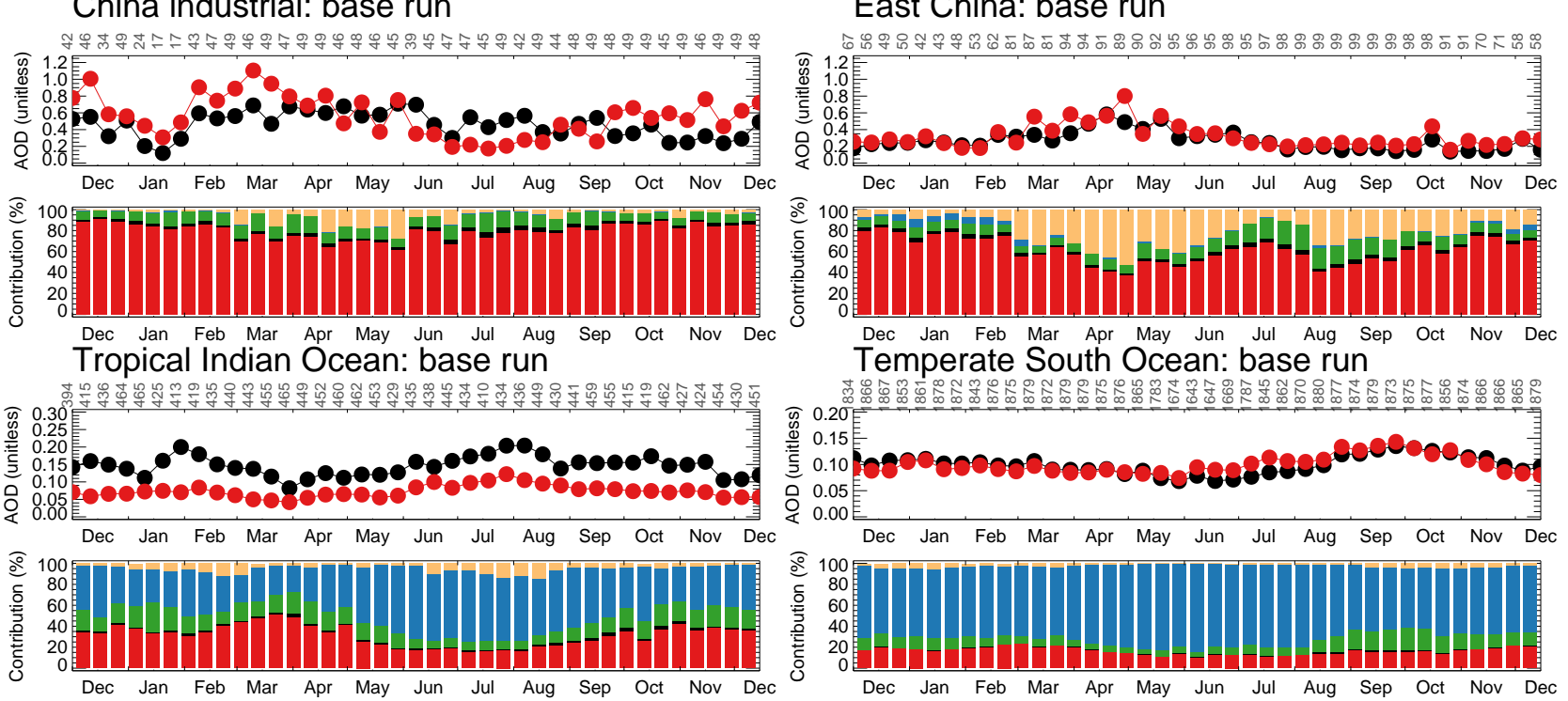

Dec Jan Feb Mar Apr May Jun Jul Aug Sep
Temperate South Ocean: base run

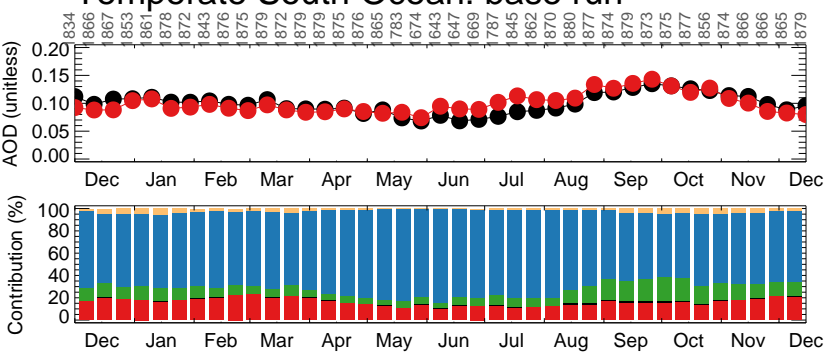

\section{Sulphate BC Organics Sea salt Desert dust}

Fig. 6. MODIS and GEOS-Chem model AOD [unitless] from December 2007-December 2008, and the model source contributions to the AOD, for Borneo, Continental Southeast Asia, Industrial China, East China, Tropical Indian Ocean, and the Temperate southern ocean; the colour key for the source contribution is given at the bottom of the figure.

furthest to tropical Atlantic Ocean, East and West USA, South Africa and temperate South America, with the slight change of $0.1 \%$. The minimal change in AOD in regions outside Southeast Asia reflects the small yield of SOA production, i.e. mass of SOA generated per mass of secondary organic gas (SOG). Significant isoprene SOA concentrations were detcted over Danum Valley during ACES/OP3 (Robinson et al., 2011a) so low sensitivity of organic aerosol to changes in isoprene emissions suggest that SOA yields used in our current model are not indicative to atmospheric formation.

\section{Conclusions}

We used the nested-grid version of the GEOS-Chem global 3-D chemistry transport model to interpret aircraft, groundbased and space-borne measurements taken during the ACES/OP3 measurement campaign over Malaysian Borneo during June-July 2008 to better understand the aerosol com- position distribution and variation over Southeast Asia region. We used the model to relate the aircraft campaign measurement to larger spatial and temporal scales so we could examine the regional impact of biogenic secondary organic aerosol.

Budget calculations for the model total column aerosol budget over Borneo and the surrounding Indonesian islands during July 2008 show the dominance of sea salt (50\%), reflecting the island geography. If we exclude coarse sea salt and desert dust, the next largest contribution to the column aerosol budget is primary organic aerosol $(43 \%)$ with sulphate and secondary organic aerosol contribution $23 \%$ and $10 \%$, respectively. We find that this region is a net-exporter of carbonaceous aerosol, of which only $10 \%$ derives from incoming air masses. The net contribution of primary OA, SOA, and BC from Borneo to downwind regions are $42 \mathrm{kT}$, $15 \mathrm{kT}$, and $11 \mathrm{kT}$ per month, respectively. The SOA contribution represents only $23.5 \%$ to the total organic aerosol despite the abundance of the BVOC precursors from the forest 
environment, mainly because only a small fraction (13\%) of the produced secondary organic gas remains in the aerosol phase. Sulphate over the region, mainly produced in-cloud from local $\mathrm{SO}_{2}$ emissions, is largely removed by precipitation within the region.

The model and measured vertical profiles of aerosol and gas concentration have the highest concentration near the surface, as expected. Measured profiles display a peak in the free troposphere between $700-800 \mathrm{hPa}$ indicative of longrange transport of pollution while local emissions dominate the profile below $900 \mathrm{hPa}$, although other studies have suggested a role for local convection (Robinson et al., 2011b). The model reproduces the $\mathrm{CO}$ concentrations profile in the FT but tends to have a positive bias in the lower troposphere, suggesting an overestimation of local burning emissions. In contrast, model sulphate concentrations fails to capture the observed peak in the FT suggesting an underestimation of long-range transport that is likely due to underestimation of sulphur emissions in the region, consistent with the evaluation against total sulphur measurements from EANET surface network. The positive model bias of BVOC emissions together with model errors due to nocturnal boundary layer mixing and/or radical chemistry contribute to the positive bias of near-surface OA concentration.

Model time series of vertical profiles of aerosol extinction over Borneo during June-July 2008 show the total AOD is determined by OA in the lowermost troposphere. This also shows that the FT is dominated by episodic long-range transport of burning emissions with coincidental elevated concentrations of $\mathrm{CO}$ and organic aerosol. This reaffirms the importance of transported pollution overlaying the relatively pristine surface environment found over forested regions.

Over Borneo and surrounding Indonesian islands, a comparison of model and MODIS space-borne total column AOD measurements reveals that the model underpredicts by $76 \%$ and captures only $14 \%$ of the variability over the year 2008 . The model attributes most of the AOD over this region to sulphate, OC and sea salt. Model AOD compares better over larger regions that are better characterized by a single source, e.g. temperate southern ocean (mainly sea salt) and East China (mainly anthropogenic sulphur). The reasons for a gross underprediction of AOD over Borneo is explored in sensitivity simulations. AOD values over Borneo are most sensitive to an increase in the organic gas-particle partitioning (22\% improvement against MODIS) but at a cost of vastly overpredicting ( $>200 \%$ ) the organic aerosol burden compared to aircraft measurements. Changes in emissions of biomass burning, anthropogenic sulphur, and DMS result in an increased aerosol burden, translating into a less substantial improvement against MODIS AOD (typically 1-5\%). A change in Southeast Asian isoprene emissions results in significant overprediction of in situ concentrations of isoprene and subsequent oxidation products, and a very small increase in organic aerosol concentrations. However, these increases in isoprene emission produces almost no change in AOD over
Borneo and other parts of the world because the model is limited by low SOA partitioning, despite evidence of significant isoprene SOA concentrations detected as the ground site during ACES/OP3. This stresses the importance of biogenic SOA on regional atmospheric components and the need to improve its formation mechanism in the model together with the knowledge of precursor VOCs emissions and associated chemistry.

Acknowledgements. We thank the ACES/OP3 team for useful discussions throughout the study and the GEOS-Chem team for continued support of the model. We acknowledge Colette Heald, Randall Martin, and Lyatt Jaeglé for providing the updated aerosol physical and optical properties for the simulation. WT and PP were funded by the UK Natural Environmental Research Council (grant number NE/E011136/1). We also thank an anonymous reviewer and A. R. MacKenzie for their helpful comments. This is paper number 527 of the Royal Society's South East Asian Rainforest Research Programme.

Edited by: R. MacKenzie

\section{References}

Alexander, B., Park, R., Jacob, D. J., Li, Q., R. M. Yantosca, J. S., Lee, C. C. W., and Thiemens, M. H.: Sulfate formation in seasalt aerosols: constraints from oxygen isotopes, J. Geophys. Res., 110, D10307, doi:10.1029/2004JD005659, 2005.

Barkley, M. P., Palmer, P. I., Ganzeveld, L., A. Arneth, D. H., Karl, T., Guenther, A., Paulot, F., Wennberg, P., Mao, J., Kurosu, T., Chance, K., Müller, J.-F., Smedt, I. D., Roozendael, M. V., Chen, D., Wang, Y., and Yantosca, R.: Can a 'state of the art' chemistry transport model really simulate Amazonian tropospheric chemistry?, J. Geophys. Res., 116, D16302, doi:10.1029/2011JD015893, 2011.

Bey, I., Jacob, D. J., Logan, J. A., and Yantosca, R. M.: Asian chemical outflow to the Pacific: Origins, pathways and budgets, J. Geophys. Res.-Atmos., 106, 23097-23113, doi:10.1029/2001JD000806, 2001a.

Bey, I., Jacob, D. J., Yantosca, R. M., Logan, J. A., Field, B. D., Fiore, A. M., Li, Q., Liu, H. G. Y., Mickley, L. J., and Schultz, M. G.: Global modeling of tropospheric chemistry with assimilated meteorology: model description and evaluation, J. Geophys. Res., 106, 23073-23095, 2001 b.

Bonan, G. B.: Forest and climate change: forcings, feedbacks, and the climate benefits of forests, Science, 320, 1444-1449, doi:10.1126/science.1155121, 2008.

Bond, T. C., Streets, D. G., Yarber, K. F., Nelson, S. M., Woo, J. -H, and Klimont, Z.: A technology-based global inventory of black and organic carbon emissions from combustion, J. Geophys. Res., 109, D14203, doi:10.1029/2003JD003697, 2004.

Chandra, S., Ziemke, J. R., Bhartia, P. K., and Martin, R. V.: Tropical tropospheric ozone: Implications for dynamics and biomass burning, J. Geophys. Res., 107, 4188, doi:10.1029/2001JD000447, 2002.

Chen, D., Wang, Y., McElroy, M. B., He, K., Yantosca, R. M., and Le Sager, P.: Regional CO pollution and export in China simulated by the high-resolution nested-grid GEOS-Chem model, At- 
mos. Chem. Phys., 9, 3825-3839, doi:10.5194/acp-9-3825-2009, 2009.

Chin, M., Rood, R. B., Lin, S. J., Muller, J. F., and Thompson, A. M.: Atmospheric sulfure cycle simulated in the global model GOCART: model description and global properties, J. Geophys. Res., 105, 24671-24687, 2000.

Drury, E., Jacob, D., Spurr, R., Wang, J., Shinozuka, Y., Anderson, B., Clarke, A., Dibb, J., McNaughton, C., and Weber, R.: Synthesis of satellite (MODIS), aircraft (ICARTT), and surface (IMPROVE, EPA-AQS, AERONET) aerosol observations over eastern North America to improve MODIS aerosol retrievals and constrain surface aerosol concentrations and sources, J. Geophys. Res., 115, D14204, doi:10.1029/2009JD012629, 2010.

Duncan, B. N., Bey, I., Chin, M., Mickley, L. J., Fairlie, T. D., Martin, R. V., and Matsueda, H.: Indonesian wildfires of 1997: Impact on tropospheric chemistry, J. Geophys. Res., 108, 4458, doi:10.1029/2002JD003195, 2003.

Fairlie, T. D., Jacob, D. J., Dibb, J. E., Alexander, B., Avery, M. A., van Donkelaar, A., and Zhang, L.: Impact of mineral dust on nitrate, sulfate, and ozone in transpacific Asian pollution plumes, Atmos. Chem. Phys., 10, 3999-4012, doi:10.5194/acp-10-39992010, 2010.

Ferreira, J., Reeves, C. E., Murphy, J. G., Garcia-Carreras, L., Parker, D. J., and Oram, D. E.: Isoprene emissions modelling for West Africa: MEGAN model evaluation and sensitivity analysis, Atmos. Chem. Phys., 10, 8453-8467, doi:10.5194/acp-10-84532010, 2010.

Fowler, D., Nemitz, E., Misztal, P., Carlo, C. D., Skiba, U., Ryder, J., Helfter, C., Cape, N., Owen, S., Dorsey, J., Gallagher, M. W., Coyle, M., Phillips, G., Davison, D., Langford, B., MacKenzie, A. R., Muller, J., Siong, J., Pyle, J. A., and Hewitt, C. N.: Effects of land use on trace gas emissions and deposition in Borneo: comparing atmosphere-surface exchange over oil palm plantations with a rainforest, Philos. T. Roy. Soc. Lond., 355, 1582, 3196-3209, doi:10.1098/rstb.2011.0055, 2011.

Fu, T-M., Jacob, D. J., Palmer, P. I., Chance, K., Wang, Y. X., Barletta, B., Blake, D. R., Stanton, J. C., and Pilling, M. J.: Spacebased formaldehyde measurements as constraints on volatile organic compound emissions in East and South Asia, J. Geophys. Res., 112, D06312, doi:10.1029/2006JD007853, 2007.

Gerbig, C., Schmitgen, S., Kley, D., Volz-Thomas, A., Dewey, K., and Haaks, D.: An improved fast-response vacuum-UV resonance fluorescence CO instrument, J. Geophys. Res., 104, 16991704, 1999.

Gonzi, S. and Palmer, P. I.: Vertical transport of surface fire emissions observed from space, J. Geophys. Res., 115, D02306, doi:10.1029/2009JD012053, 2010.

Griffin, R. J., Cocker III, D. R., Seinfeld, J. H., and Dabdub, D.: Estimate of global atmospheric organic aerosol from oxidation of biogenic hydrocarbons, Geophys. Res. Lett., 26, 2721-2724, doi:10.1029/1999GL900476, 1999.

Guenther, A., Karl, T., Harley, P., Wiedinmyer, C., Palmer, P. I., and Geron, C.: Estimates of global terrestrial isoprene emissions using MEGAN (Model of Emissions of Gases and Aerosols from Nature), Atmos. Chem. Phys., 6, 3181-3210, doi:10.5194/acp-63181-2006, 2006.

Hamilton, J. F., Rami Alfarra, M., Wyche, K. P., Ward, M. W., Lewis, A. C., McFiggans, G. B., Good, N., Monks, P. S., Carr, T., White, I. R., and Purvis, R. M.: Investigating the use of secondary organic aerosol as seed particles in simulation chamber experiments, Atmos. Chem. Phys., 11, 5917-5929, doi:10.5194/acp-11-5917-2011, 2011.

Heald, C. L., Jacob, D. J., Jones, D. B. A., Palmer, P. I., Logan, J. A., Streets, D. G., Gille, G. W., Hoffman, R. N., and Nehrkorn, T.: Comparative inverse analysis of satellite (MOPITT) and aircraft (TRACE-P) observations to estimate Asian sources of carbon monoxide, J. Geophys. Res., 109, D23306, doi:10.1029/2004JD005185, 2004.

Henze, D. K. and Seinfeld, J. H.: Global secondary organic aerosol from isoprene oxidation, Geophys. Res. Lett., 33, L09812, doi:10.1029/2006GL025976, 2006.

Hewitt, C. N., MacKenzie, A. R., Carlo, P. D., Dorsey, J. R., Evans, M., Fowler, D., Gallagher, M. W., Helfter, C., Hopkinds, J., Jones, H., Langford, B., Lee, J. D., Lewis, A. C., Lim, S. F., di Marco, C., Misztal, P., Moller, S., Monks, P. S., Nemitz, E., Oram, D. E., Owen, S. M., Phillips, G., Pugh, T., Pyle, J. A., Reeves, C. E., Ryder, J., Siong, J., Skiba, U., Stewart, D. J., and Thomas, R.: Nitrogen management is essential to prevent tropical oil palm plantations from causing ozone pollution, P. Natl. Acad. Sci., 106, 18447-18451, 2009.

Hewitt, C. N., Lee, J. D., MacKenzie, A. R., Barkley, M. P., Carslaw, N., Carver, G. D., Chappell, N. A., Coe, H., Collier, C., Commane, R., Davies, F., Davison, B., DiCarlo, P., Di Marco, C. F., Dorsey, J. R., Edwards, P. M., Evans, M. J., Fowler, D., Furneaux, K. L., Gallagher, M., Guenther, A., Heard, D. E., Helfter, C., Hopkins, J., Ingham, T., Irwin, M., Jones, C., Karunaharan, A., Langford, B., Lewis, A. C., Lim, S. F., MacDonald, S. M., Mahajan, A. S., Malpass, S., McFiggans, G., Mills, G., Misztal, P., Moller, S., Monks, P. S., Nemitz, E., Nicolas-Perea, V., Oetjen, H., Oram, D. E., Palmer, P. I., Phillips, G. J., Pike, R., Plane, J. M. C., Pugh, T., Pyle, J. A., Reeves, C. E., Robinson, N. H., Stewart, D., Stone, D., Whalley, L. K., and Yin, X.: Overview: oxidant and particle photochemical processes above a south-east Asian tropical rainforest (the OP3 project): introduction, rationale, location characteristics and tools, Atmos. Chem. Phys., 10, 169-199, doi:10.5194/acp-10169-2010, 2010.

Hodzic, A., Jimenez, J. L., Madronich, S., Aiken, A. C., Bessagnet, B., Curci, G., Fast, J., Lamarque, J.-F., Onasch, T. B., Roux, G., Schauer, J. J., Stone, E. A., and Ulbrich, I. M.: Modeling organic aerosols during MILAGRO: importance of biogenic secondary organic aerosols, Atmos. Chem. Phys., 9, 6949-6981, doi:10.5194/acp-9-6949-2009, 2009.

Jaeglé, L., Quinn, P. K., Bates, T. S., Alexander, B., and Lin, J.-T.: Global distribution of sea salt aerosols: new constraints from in situ and remote sensing observations, Atmos. Chem. Phys., 11, 3137-3157, doi:10.5194/acp-11-3137-2011, 2011.

Jimenez, J. L., Canagaratna, M. R., Donahue, N. M., Prevot, A. S. H., Zhang, Q., Kroll, J. H., DeCarlo, P. F., Allan, J. D., Coe, H., Ng, N. L., Aiken, A. C., Docherty, K. S., Ulbrich, I. M., Grieshop, A. P., Robinson, A. L., Duplissy, J., Smith, J. D., Wilson, K. R., Lanz, V. A., Hueglin, C., Sun, Y. L., Tian, J., Laaksonen, A., Raatikainen, T., Rautiainen, J., Vaattovaara, P., Ehn, M., Kulmala, M., Tomlinson, J. M., Collins, D. R., Cubison, M. J., Dunlea, E. J., Huffman, J. A., Onasch, T. B., Alfarra, M. R., Williams, P. I., Bower, K., Kondo, Y., Schneider, J., Drewnick, F., Borrmann, S., Weimer, S., Demerjian, K., Salcedo, D., Cottrell, L., Griffin, R., Takami, A., Miyoshi, T., Hatakeyama, S., 
Shimono, A., Sun, J. Y., Zhang, Y. M., Dzepina, K., Kimmel, J. R., Sueper, D., Jayne, J. T., Herndon, S. C., Trimborn, A. M., Williams, L. R., Wood, E. C., Middlebrook, A. M., Kolb, C. E., Baltensperger, U., and Worsnop, D. R.: Evolution of Organic Aerosols in the Atmosphere, Science, 326, 1525-1529, 2009.

Karl, T., Harley, P., Emmons, L., Thornton, B., Guenther, A., Basu, C., Turnipseed, A., and Jardine, K.: Efficient Atmospheric Cleansing of Oxidized Organic Trace Gases by Vegetation, Science, 330, 816-819, doi:10.1126/science.1192534, 2010.

Kiley, C., Fuelberg, H. E., Palmer, P. I., Allen, D., Carmichael, G. R., Jacob, D. J., Mari, C., Pierce, B., Pickering, K., Tang, Y., Wild, O., Fairlie, T. D., Logan, J. A., and Streets, D. G.: An intercomparison and evaluation of aircraft-derived and simulated $\mathrm{CO}$ from seven chemical transport model during the TRACE-P experiment, J. Geophys. Res., 108, 8819, doi:10.1029/2002JD003089, 2003.

Kopacz, M., Jacob, D. J., Fisher, J. A., Logan, J. A., Zhang, L., Megretskaia, I. A., Yantosca, R. M., Singh, K., Henze, D. K., Burrows, J. P., Buchwitz, M., Khlystova, I., McMillan, W. W., Gille, J. C., Edwards, D. P., Eldering, A., Thouret, V., and Nedelec, P.: Global estimates of CO sources with high resolution by adjoint inversion of multiple satellite datasets (MOPITT, AIRS, SCIAMACHY, TES), Atmos. Chem. Phys., 10, 855-876, doi:10.5194/acp-10-855-2010, 2010.

Kuhns, H., Knipping, E. M., and Vukovich, J. M.: Development of United States-Mexico emissions inventory for the Big Bend Regional Aerosol and Visiting Observational (BRAVE) Study, J. Waste Manage. Assoc., 55, 677-692, 2005.

Kulshrestha, U., Jain, M., Sekar, R., Vairamani, M., Sarkar, A., and Parashar, D.: Chemical characteristics and source apportionment of aerosols over Indian Ocean during INDOEX-1999, Current Science, 80, 180-185, 2001.

Langford, B., Misztal, P. K., Nemitz, E., Davison, B., Helfter, C., Pugh, T. A. M., MacKenzie, A. R., Lim, S. F., and Hewitt, C. N.: Fluxes and concentrations of volatile organic compounds from a South-East Asian tropical rainforest, Atmos. Chem. Phys., 10, 8391-8412, doi:10.5194/acp-10-8391-2010, 2010.

Lelieveld, J., Butler, T. M., Crowley, J. N., Dillon, T. J., Fischer, H., Ganzeveld, L., Harder, H., Lawrence, M. G., Martinez, M., Taraborelli, D., and Williams, J.: Atmospheric oxidation capacity sustained by a tropical forest, Nature, 452, 737-740, 2008.

Levy, R. C., Remer, L. A., Tanre, D., Kaufman, Y. J., Ichoku, C., Holben, B. N., Livingston, J. M., Russell, P. B., and Maring, H.: Evaluation of the Moderate-Resolution Imaging Spectroradiometer (MODIS) retrievals of dust aerosol over the ocean during PRIDE, J. Geophys. Res., 108, 8594, doi:10.1029/2002JD002460, 2003.

Levy, R. C., Remer, L. A., Mattoo, S., Vermote, E. F., and Kaufman, Y. J.: Second-generation operational algorithm: Retrieval of aerosol properties over land from inversion of Moderate Resolution Imaging Spectroradiometer spectral reflectance, J. Geophys. Res., 112, D13211, doi:10.1029/2006JD007811, 2007.

Levy, R. C., Remer, L. A., and Dubovik, O.: Global aerosol optical properties and application to Moderate Resolution Imaging Spectroradiometer aerosol retrieval over land, J. Geophys. Res., 112, D13210, doi:10.1029/2006JD007815, 2007.

Levy, R. C., Remer, L. A., Kleidman, R. G., Mattoo, S., Ichoku, C., Kahn, R., and Eck, T. F.: Global evaluation of the Collection 5 MODIS dark-target aerosol products over land, Atmos. Chem.
Phys., 10, 10399-10420, doi:10.5194/acp-10-10399-2010, 2010. Lewis, S. L., Mahli, Y., and Phillips, O. L.: Fingerprinting the impacts of global change on tropical forests, Philos. T. Roy. Soc. Lond. B, 359, 437-462, 2004.

MacKenzie, A. R., Langford, B., Pugh, T. A. M., Robinson, N., Misztal, P. K., Heard, D. E., Lee, J. D., Lewis, A. C., Jones, C. E., Hopkins, J. R., Philips, G., Monks, P. S., Karunaharan, A., Hornsby, K. E., Nicholas-Perea, V., Coe, H., Whalley, L. K., Edwards, P. M., Evans, M. J., Stone, D., Ingham, T., Commane, R., Furneaux, K. L., McQuaid, J., Nemitz, E., Seng, Y. K., Fowler, D., Pyle, J. A., and Hewitt, C. N.: The atmospheric chemistry of trace gases and particulate matter emitted by different land uses in Borneo, Philos. T. Roy. Soc. Lond., 366, 1582, 3177-3195, doi:10.1098/rstb.2011.0053, 2011.

Marticorena, B., Haywood, J., Coe, H., Formenti, P., Liousse, C., Mallet, M., and Pelon, J.: Tropospheric aerosols over West Africa: highlights from the AMMA international program, Atmos. Sci. Lett., 12, 19-23, 2011.

Martin, S. T., Andreae, M. O., Althausen, D., Artaxo, P., Baars, H., Borrmann, S., Chen, Q., Farmer, D. K., Guenther, A., Gunthe, S. S., Jimenez, J. L., Karl, T., Longo, K., Manzi, A., Müller, T., Pauliquevis, T., Petters, M. D., Prenni, A. J., Pöschl, U., Rizzo, L. V., Schneider, J., Smith, J. N., Swietlicki, E., Tota, J., Wang, J., Wiedensohler, A., and Zorn, S. R.: An overview of the Amazonian Aerosol Characterization Experiment 2008 (AMAZE-08), Atmos. Chem. Phys., 10, 11415-11438, doi:10.5194/acp-1011415-2010, 2010a.

Martin, S. T., Andreae, M. O., Artaxo, P., Baumgardner, D., Chen, Q., Goldstein, A. H., Guenther, A., Heald, C. L., MayolBracero, O. L., McMurry, P. H., Pauliquevis, T., Poeschl, U., Prather, K. A., Roberts, G. C., Saleska, S. R., Silva Dias, M. A., Spracklen, D. V., Swietlicki, E., and Trebs, I.: Sources and properties of Amazonian aerosol particles, Rev. Geophys., 48, RG2002, doi:10.1029/2008RG000280, 2010b.

Misztal, P. K., Owen, S. M., Guenther, A. B., Rasmussen, R., Geron, C., Harley, P., Phillips, G. J., Ryan, A., Edwards, D. P., Hewitt, C. N., Nemitz, E., Siong, J., Heal, M. R., and Cape, J. N.: Large estragole fluxes from oil palms in Borneo, Atmos. Chem. Phys., 10, 4343-4358, doi:10.5194/acp-10-4343-2010, 2010.

Morgan, W. T., Allan, J. D., Bower, K. N., Highwood, E. J., Liu, D., McMeeking, G. R., Northway, M. J., Williams, P. I., Krejci, R., and Coe, H.: Airborne measurements of the spatial distribution of aerosol chemical composition across Europe and evolution of the organic fraction, Atmos. Chem. Phys., 10, 4065-4083, doi:10.5194/acp-10-4065-2010, 2010.

Müller, J.-F., Stavrakou, T., Wallens, S., De Smedt, I., Van Roozendael, M., Potosnak, M. J., Rinne, J., Munger, B., Goldstein, A., and Guenther, A. B.: Global isoprene emissions estimated using MEGAN, ECMWF analyses and a detailed canopy environment model, Atmos. Chem. Phys., 8, 1329-1341, doi:10.5194/acp-81329-2008, 2008.

Murphy, J. G., Oram, D. E., and Reeves, C. E.: Measurements of volatile organic compounds over West Africa, Atmos. Chem. Phys., 10, 5281-5294, doi:10.5194/acp-10-5281-2010, 2010.

Myneni, R. B., Yang, W., Nemani, R. R., Huete, A. R., Dickinson, R. E., Knyazikhin, Y., Didan, K., Fu, R., Juarez, R. I. N., Saatchi, S. S., Hashimoto, H., Ichii, K., Shabanov, N. V., Tan, B., Ratana, P., Privette, J. L., Morisette, J. T., Vermote, E. F., Roy, D. P., Wolfe, R. E., Friedl, M. A., Running, S. W., Votava, 
P., El-Saleous, N., Devadiga, S., Su, Y., and Salomonson, V. V.: Large seasonal swings in leaf area of Amazon rainforests, P. Natl. Acad. Sci., 104, 4820-4823, 2007.

Palmer, P. I., Jacob, D. J., Jones, D. B. A., Heald, C. L., Yantosca, R. M., Logan, J. A., Sachse, G. W., and Streets, D. G.: Inverting for emissions of carbon monoxide from Asia using aircraft observations over the western Pacific, J. Geophys. Res., 108, 8825, doi:10.1029/2002JD003176, 2003.

Palmer, P. I., Suntharalingam, P., Jones, D. B. A., Jacob, D. J., Streets, D. G., Fu., Q., Vay, S., and Sachse, G. W.: Using $\mathrm{CO}_{2}$ :CO correlations to improve inverse analyses of carbon fluxes, J. Geophys. Res., 111, D12318, doi:10.1029/2005JD006403, 2006.

Park, R. J., Jacob, D. J., Chin, M., and Martin, R. V.: Sources of carbonaceous aerosols over the United States and implications for natural visibility, J. Geophys. Res., 108, 4355, doi:10.1029/2002JD003190, 2003.

Park, R. J., Jacob, D. J., Field, B. D., Yantosca, R. M., and Chin, M.: Natural and transboundary pollution influences on sulfate-nitrate-ammonium aerosols in the United States: implications for policy?, J. Geophys. Res., 109, D15204, doi:10.1029/2003JD004473, 2004.

Park, R. J., Jacob, D. J., Palmer, P. I., Clarke, A. D., Weber, R. J., Zondlo, M. A., Eisele, F. L., Bandy, A. R., Thornton, D. C., Sachse, G. W., and Bond, T. C.: Export efficiency of black carbon aerosol in continental outflow: global implications, J. Geophys. Res., 110, D11205, doi:10.1029/2004JD005432, 2005.

Pearson, G., Davies, F., and Collier, C.: Remote sensing of the tropical rain forest boundary layer using pulsed Doppler lidar, Atmos. Chem. Phys., 10, 5891-5901, doi:10.5194/acp-10-58912010, 2010.

Pike, R. C., Lee, J. D., Young, P. J., Carver, G. D., Yang, X., Warwick, N., Moller, S., Misztal, P., Langford, B., Stewart, D., Reeves, C. E., Hewitt, C. N., and Pyle, J. A.: $\mathrm{NO}_{\mathrm{x}}$ and $\mathrm{O}_{3}$ above a tropical rainforest: an analysis with a global and box model, Atmos. Chem. Phys., 10, 10607-10620, doi:10.5194/acp10-10607-2010, 2010.

Pugh, T. A. M., MacKenzie, A. R., Hewitt, C. N., Langford, B., Edwards, P. M., Furneaux, K. L., Heard, D. E., Hopkins, J. R., Jones, C. E., Karunaharan, A., Lee, J., Mills, G., Misztal, P., Moller, S., Monks, P. S., and Whalley, L. K.: Simulating atmospheric composition over a South-East Asian tropical rainforest: performance of a chemistry box model, Atmos. Chem. Phys., 10, 279-298, doi:10.5194/acp-10-279-2010, 2010.

Pugh, T. A. M., MacKenzie, A. R., Langford, B., Nemitz, E., Misztal, P. K., and Hewitt, C. N.: The influence of small-scale variations in isoprene concentrations on atmospheric chemistry over a tropical rainforest, Atmos. Chem. Phys., 11, 4121-4134, doi:10.5194/acp-11-4121-2011, 2011.

Pyle, J. A., Ashfold, M. J., Harris, N. R. P., Robinson, A. D., Warwick, N. J., Carver, G. D., Gostlow, B., O’Brien, L. M., Manning, A. J., Phang, S. M., Yong, S. E., Leong, K. P., Ung, E. H., and Ong, S.: Bromoform in the tropical boundary layer of the Maritime Continent during OP3, Atmos. Chem. Phys., 11, 529-542, doi:10.5194/acp-11-529-2011, 2011a.

Pyle, J. A., Warwick, N. J., Harris, N. R. P., Abas, M. R., Archibald, A., Ashfold, M. J., Ashworth, K., Barkley, M. P., Carver, G. D., Chance, K., Dorsey, J., Fowler, D., Gonzi, S., Gostlow, B., Hewitt, C. N., Kurosu, T. P., Lee, J. D., Langford, S. B., Mills,
G., Moller, S., MacKenzie, A. R., Manning, A. J., Misztal, P., Nadzir, M. S. M., Nemitz, E., Newton, H., O’Brien, L. M., Ong, S., Oram, D., Palmer, P. I., Peng, L. K., Phang, S. M., Pike, R., Pugh, T. A. M., Rahman, N. A., Robinson, A. D., Sentian, J., Samah, A. A., Skiba, U., Ung, H. E., Yong, E. E., and Young, P.: The impact of local land surface changes in Borneo on atmospheric composition at wider spatial scales: coastal processes, land use change and air quality, Philos. T. Roy. Soc. Lond., 366, 1582, 3210-3224, doi:10.1098/rstb.2011.0060, 2011 b.

Remer, L. A., Kaufman, Y. J., Tanre, D., Mattoo, S., Chu, D. A., Martins, J. V., Li, R. -R., and Ichoku, C., Levy, R. C., Kleidman, R. G., Eck, T. F., Vermote, E., and Holben, B. N.: The MODIS Aerosol Algorithm, Products, and Validation, J. Atmos. Sci., 62, 947-972, doi:10.1175/JAS3385, 2005.

Robinson, N. H., Hamilton, J. F., Allan, J. D., Langford, B., Oram, D. E., Chen, Q., Docherty, K., Farmer, D. K., Jimenez, J. L., Ward, M. W., Hewitt, C. N., Barley, M. H., Jenkin, M. E., Rickard, A. R., Martin, S. T., McFiggans, G., and Coe, H.: Evidence for a significant proportion of Secondary Organic Aerosol from isoprene above a maritime tropical forest, Atmos. Chem. Phys., 11, 1039-1050, doi:10.5194/acp-11-1039-2011, $2011 \mathrm{a}$.

Robinson, N. H., Newton, H. M., Allan, J. D., Irwin, M., Hamilton, J. F., Flynn, M., Bower, K. N., Williams, P. I., Mills, G., Reeves, C. E., McFiggans, G., and Coe, H.: Source attribution of Bornean air masses by back trajectory analysis during the OP3 project, Atmos. Chem. Phys., 11, 9605-9630, doi:10.5194/acp-11-96052011, 2011b.

Robinson, N. H., Allan, J. D., Trembath, J. A., Rosenberg, P. D., Allen, G., and Coe, H.: The lofting of Western Pacific regional aerosol by island thermodynamics as observed around Borneo, Atmos. Chem. Phys. Discuss., 12, 1215-1265, doi:10.5194/acpd-12-1215-2012, 2012.

Sakulyanontvittya, T., Duhl, T., Wiedinmyer, C., Helmig, D., Matsunaga, S., Potosnak, M., Milford, J., and Guenther, A.: Monoterpene and sesquiterpene emission estimates for the United States, Environ. Sci. Tech., 42, 1623-1629, 2008.

Shim, C., Wang, Y., Choi, Y., Palmer, P. I., Abbot, D. S., and Chance, K.: Constraining global isoprene emissions with Global Ozone Monitoring Experiment (GOME) formaldehyde column measurements, J. Geophys. Res., 110, D24301, doi:10.1029/2004JD005629, 2005.

Streets, D., Bond, T., Carmichael, G., Fernandes, S., Fu, Q., He, D., Klimont, Z., Nelson, S., Tsai, N., Wang, M., Woo, J., and Yarber, K.: An inventory of gaseous and primary aerosol emissions in Asia in the year 2000, J. Geophys. Res, 108, 8809, doi:10.1029/2002JD003093, 2003.

Streets, D. G., Zhang, Q., Wang, L., He, K., Hao, J., Wu, Y., Tang, Y., and Carmichael, G. R.: Revisiting China's CO emissions after the Transport and Chemical Evolution over the Pacific (TRACE-P) mission: Synthesis of inventories, atmospheric modeling, and observations, J. Geophys. Res., 111, D14306, doi:10.1029/2006JD007118, 2006.

Tanre, D., Kaufman, Y. J., Herman, M., and Mattoo, S.: Remote sensing of aerosol properties over oceans using the MODIS/EOS spectral radiances, J. Geophys. Res., 102, 1697116988, doi:10.1029/96JD03437, 1997.

Tegen, I. and Lacis, A. A.: Modeling of particle size distribution and its influence on the radiative properties of mineral dust aerosol, J. Geophys. Res., 101, 19237-19244, 1996. 
Wang, Y. X. X., McElroy, M. B., Jacob, D. J., and Yantosca, R. M.: A nested-grid formulation for chemical transport over Asia: applications to CO, J. Geophys. Res., 109, D22307, doi:10.1029/2004JD005237, 2004.

van der Werf, G. R., Randerson, J. T., Giglio, L., Collatz, G. J., Kasibhatla, P. S., and Arellano Jr., A. F.: Interannual variability in global biomass burning emissions from 1997 to 2004, Atmos. Chem. Phys., 6, 3423-3441, doi:10.5194/acp-6-3423-2006, 2006.
Whitehead, J. D., Gallagher, M. W., Dorsey, J. R., Robinson, N., Gabey, A. M., Coe, H., McFiggans, G., Flynn, M. J., Ryder, J., Nemitz, E., and Davies, F.: Aerosol fluxes and dynamics within and above a tropical rainforest in South-East Asia, Atmos. Chem. Phys., 10, 9369-9382, doi:10.5194/acp-10-9369-2010, 2010. 